University of Louisville

ThinkIR: The University of Louisville's Institutional Repository

Electronic Theses and Dissertations

1940

\title{
The Polish Corridor.
}

James Otis Kelley

University of Louisville

Follow this and additional works at: https://ir.library.louisville.edu/etd

Part of the Diplomatic History Commons, and the European History Commons

\section{Recommended Citation}

Kelley, James Otis, "The Polish Corridor." (1940). Electronic Theses and Dissertations. Paper 1817. https://doi.org/10.18297/etd/1817

This Master's Thesis is brought to you for free and open access by ThinkIR: The University of Louisville's Institutional Repository. It has been accepted for inclusion in Electronic Theses and Dissertations by an authorized administrator of ThinkIR: The University of Louisville's Institutional Repository. This title appears here courtesy of the author, who has retained all other copyrights. For more information, please contact thinkir@louisville.edu. 


\title{
UIIVERSITY OF IOUISVILIE
}

\author{
THE POIISH CORRIDOR
}

4 Dissertation

Submittod to the Faculty

of the Graduate school of the University of Lonigville

In partial Fulfilimont of the

Requirements for the Degree

of yaster of Arts

Departmont of H18tory

by

James Ot18 Kellog

1940 
name of student:

Title of The 818: THE POLISH CORRIDOR

Ire of Director:

Approved by a reading committee composed of the following members:

Date: Gan nary 25,1540 


\section{TABIE OF COITENTS}


TABLE OF CONTENTS

page

Tho Introduction ............... 1

I. Definition

II. Reasons For This study

III. Tho Bigniflcance of Poland's Roappearence

IV. The Treaty of Versaillea

Chapter I. Tho Partitiona ......... - 5

I. Poland Partitioned by Three of Her Heighbor:

4. Classic example of international Trong

1. Denounced by Thomas Jefferson

2. Denounced by George

Clemenoesin

B. Poland - a large country

c. The idea of partitionting Poland was not now

D. Frederiok the Great' part

B. The Poles revise their constitution

F. The confederation of Targowica formed

II. The First partition

A. The land distribution 
III. The Seoond pertition

A. The land distribution

B. Less excuse for second partition

IV. The Third Partition

A. The land distribution

V. Some Observations on Poland' Undoing

Chapter II. From the partitions to the Peace Conference. . .......

I. Poles Deprived of Dnity and Freedom 111 Through the Nineteenth Contury

4. Bra of new growth of democracy

B. Achierements in science and teohnology

C. Perlod of awakening of natione

II. Kost Romantic Militarg Adventurers in the Forld

A. Followed rapoloon for twonty yeare

B. Poles found wherever a netion otruggled for liberty

C. Robelled many timea

III. At the Close of the Nineteonth Century Their Cause Seemed Dead 
page

1. Prance had formed an alliance with Russia

B. Austria was drifting toward Germany

C. The Poles were giving up

IV. The War Opened Uf a Gloom Prospect for the Poles in 1914

1. Promises of freodom were alwaye vague

B. All thought the Polleh cause just

C. Both sides would have to be beaten

V. Rays of Iight Appear

A. Russian retolution exercised decisive influenoe

B. President Wilson forored a reunited and free Poland

VI. The central Powers Fere Defeated and Asked for an Armistice

VII. Other SIgnificant Erents

Chepter III. The Peace Conference........ 4 I

I. Poles Were Admitted to the Peace Conference

A. Poland's representatives

B. The memories of a great Polend gave trouble

C. Spocial commissions

D. M. Dmowski's views

B. Joseph Pilsudski's viewa 
II. Poland's Territorial Claime

4. Poland would not bo atiofied with historical boundarion in the west

B. Silosia should be lncluded

c. Bastern Germany had beon Germanized

D. The territory was polioh whioh had been suppressed by ant1P0118h 1awe

III. Tro rain Tendenoles wanifested in the Conference

IV. Nationality Chief Basis of Settlemont

V. Different Viewe on Poland

Chapter IV. Thet Territory Should Poland Include? 68

I. Why Should Poland Be Restored?

1. Sho had had a great past

B. It was right

C. Polos wanted it

D. Bquilibrium of Central Burope rould be restored

II. That Criterio Should be Used in Betablishing Boundarles?

III. Some Commente on a Proper Boundary 
pare

Chapter V. Tho Polish Corridor ........ 64

I. Basis of claims to the Corridor

A. Historicel

B. Ethnical

C. Economio

. II. Territory of the Corridor Hard to Sottlo

III. Some Thought the Territorial Awarde to Poland Were roo Iarge

A. Generel smut's atatoment

IV. Some Suggerted Alternativea

A. Permit Poland to use oertain Gorman port:

B. Put Danzig, the Corridor, and Bast Prusaia in a neutral zone

C. Gire Poland an outlet to the Bea further east

v. Denzig a Unique Creation

A. Too many Germans in Danzig to give it outright to Poland

B. The German protest against the final arrangement

C. Explanation for taking Danzig Irom Gormany

VI. Gyania

A. Regsons for bullaing

B. The port's splendid location 
pare

VII. Did Poland Really reed a port?

Chaptor VI. German-Polish Reletions Since the War.............. 99

I. The Polieh Foreign Polioy

1. To keop peaco with Germeny and Russia

B. To make Poland strong

II. German Polloy Toward Poland

A. Peace treatios intolerable

B. Poland a temporary atete

C. Hastened the building of Gaymia

III. Chanoellor Hitler'o Regime

A. H1tler's Konigsberg addrese

B. The Hon-Aggreasion pact

1. To remain in force ten yeare

IV. Renewing Nlizanoee

A. With Roumania

B. Chamberlain's opeoch

V. President Roosevelt's Request

VI. How Hitler Tirade

A. Vanted a fifteen mile wide highway acrose the Corridor

B. Hitler invados Poland

C. Rugsia comes in

D. Poland partitioned by Germany and Ruseia 
The Conclusion ................ 114

I. Who Should Have Had the Corridor?

A. According to history - the poles

B. Ethnicalig - the Poles

C. Boonomio8lly - it was of more value to the Polea

Blbllography . . . . . . . . . . . . 117 
INPRODUCTIOI 


\section{INTRODUCTION}

\section{"Dofinitive Lepecta"}

The "polish Corridor" was a derisive designation given by the Germans, to a certain portion or aector of land, bordering on the Belt10 sea in Northern Enope. While $80 \mathrm{mo}$ of the Corridor lay on the east of the vistula Rirer, most of it was to the west of that main Polish arterg. It was of tuated between Pomerania on the west, and Danzig and East Prussia on the esst. ${ }^{1}$ The Corridor was wedge shaped, of varying widths, but widest at its southernmost boundary. 2

It was usuelly assumed thet the Corridor compriaes approximately those parts of the former German protinces of West Prussia and Posen extending from Bomberg (Bydgoseca) to the Baltic. 3

This region was a part of the German Bmpire up unt1l the close of the World War. It embodied the -fforts of the Peace Conference at Versailles to gito to the Poles a free and secure aceese to the sea." I. Derron, WIIram Harbat, Germany Under the lreaty, p. 108

2. Ib1d., p. 102

3. Stone, Shepard, "German Polish Disputes," Forelgn Polley Reporte, Vol. IX, No. 9, p. 102, JuIg 6, I933

4. Sejmour, Charles, The Intimate papers of colonel Hopse, Vol. IV, p. 200 
It is the purpose of this study to inquire into the history, the motive for, the justice and the expedieney of this creation or allocation by the Peace Conference.

The reappearance of Poland at the Paris Peace Conference in 1919 was one of the most aignifieant and unique events in our age. I notion which had had a groat and memorablo past and which had undergone disesction in peace time at the hands of 1 to greedy noighbors, came to life again, and was sooking once more a loogl habitation and a name. Thi 81gnifled somothing more than the mere revival of a raniahed state: It stood for the triumphant righting of one of the greatest political wrongs that Earope had ever witnessed, the vindication of the prinolples of justice, right, and fair doaltng in international rolations. ${ }^{1}$

The Treaty of Versaille has been termed by some as Carthaginian Peace. 2 The opithet, which implies injustice, or treachery, is misleading. The political mep of Europe, as it ha been drawn in the peace treaties, no doubt, compares favorably with the map Some Problems of the Peace Conferenoe, p. 163 2. Djbosk1, Roman, poIand, p. 9 
which it replaced and was more elosely in acoord with the wishes of the populations concerned then any previous arrangements of land aress in Europesn history.

The real objection to the Freaties was not that they were ungust, but that they wore too impractioal and idealistion The Festern slav, the universel bondman of the early Mdale Ages, is delivered from the routon, the Muecovite and the Megrar. ${ }^{1}$ W11l these glar states which have beon created by the Treatios, establish themelves in the esteem and confidenoe of Irope, will they be economioally sound units, and can they ouccesefully resist the dangers which may proceed from the vallant unreconolled aristocracies of Prussia, Russia, and Austrie? These questions, the future alone can anerer.

of all the net creations by the peace treatios, Poland was the most important, the most interesting, and the most controversial. All through history the Poles, 11ke the Irigh, have been in the center of the otrife: combative, adventurous, temperamental, irrepreseiblo. Their annels have been marked by extromo viciseitudes of fortune; at one time they have been masters of a 
wide Emplre stretohing from the Baltic to the Black soe, at another timo, partitioned and obliterated. ${ }^{1}$ If one of the requialtes of a sorereign state is a body of people occupying a particular territory and politically organized under one government, Poland was not a sovereign state when it appeared at Versaillee, for it was not organized potentially or actually under one government, nor did it occupy a definite territory. It was merely a phantom roaming around in the northerm plaine somowhere betweon Gormany and Russia; and what this disembodied opirit would look like if olothed again in flesh and blood, no one actually knew. 2 It was, then, to be a part of the work of the Peace Conference to mark out and to determine its boundaries.

It may be illuminating at this point to inquire into the manner of poland's extinction as a nation in the eighteenth century, and to rehearse the events and actions that brought about its partitions. Attention might be focused on the fact that at the time of Poland's exit from the family of nations, the so called, "polish Corridor," was an undisputed part of polish territorg.

1. Dgbo日k, Koman, Op. CIt., pp. 9-10

2. Haskins, Charles Homer and Lord, Robert Howard, op. Cit., pp. 156-57 
CHAPTER I

THE PARTITIONS 


\section{CHAPTER I}

\section{THE PARTITIONS}

The Partitions of Poland by 1 ts three close noighbors: Rus81a, Prussia, and Lustria in 1778, 1793, and 2795 have long been considered the elassic example of international wrong and crime in the -ighteenth contury. Ho loss a person than Thomas Jofferson, third President of the Onited states, has denounced the partitions of Poland as a "baneful prooedent," a "crime," and an "atrocity."

George Clemencean said that the partition of Poland was the greatest crimo in history, also that It loft an everlasting atigma on the names of Catherine, Maria Theresa, and Froderick II.

"Ho outrage had ever less exouse, no violence perpotrated against humanity over oried louder for a redress that had beon indefinitely postponod. The wrong was so great that no timo in the life of Burope, among so many other acts of violence for which there was no expiation, could it appear less heinous. It has become a byword in history as one of the worst felonieg that can be laid to the charge of our ofvilization. $n^{2}$

1. Hasing, Charles Homer and Lord, Robert Howard, Op. C1t.. p. 154

2. Clemencean, George, Grandenr and Misery of Victory. p. 193 
Some writers profess to trace the idea of the pertition of Poland back for more than a century before it was an accomplished fact. ${ }^{1}$ certainly the 1dea was not new. It had been discussed as early as 1656 by Charles $X$ of sweden and the Great flector, Frederick Filliam; and for a century the 1dea hanted the statesmon of many Furopean countries, emerging in the sinister helf ehadows of momorande and projeots. only to be buried to a troubled rest. Whether Frederick the Great was the first anthor of a definite scheme is disputable and Irrelerant and inconsequential to the main derelopment.

The second or third largest state in Burope with an area of 282,000 equare miles, standing fourth in population with orer 11,000,000 people, had been destroyod. 2 Its frontier had extended from the Baltio Sea and the Carpathian Mountains to the Dneiper and the Drine Rivera. It included nearly the whole of that broad isthme between the Baltic sea and the Black sea which leads from Eastern Continental Burope to the peninenlar Europe of the Fest. ${ }^{3}$ Heverthelese, it had been completely and totally obliterated from the map of

\footnotetext{
I. Larriott, J. H. K, and RobortBon, C. G., the Erolution of Pruseia, pp. 151-58

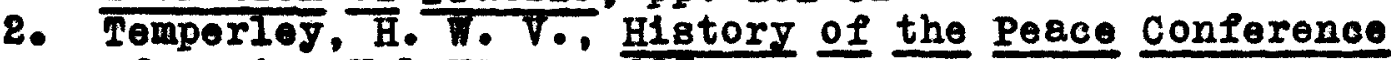
of Paris. Vol.VI, p. 223

3. Ibid., p. 228
} 
Europe by 1ts great land grabbing and land hangry neighbors. ${ }^{2}$

certain observations of Poland's historical catastrophe, namely the three partition, easily enggest themselves to the outside observer indifferently conversant with general European history. 2 Thus, som bearings of Poland's geographical position on her fate are obrious enough. That position was a "keg" position at the crossing of old establishod and important trade routes between the northern and southern seas, and the western and eastern lands of Rurope. 3 Is ench, it was bound to make Poland a flourishing power in international trade in the Mddale Ages; but it ineritably lost its advantages with the closing up of Buropean south-oast by the Turkish conquest, and then the opening up of a new world across the western seas for European trade; commereial wealth, and with it political power were fated to ebb away from Poland in the modern era quito as easy as it was fated to obb amay from tho Venetian and other Italian Republica. 4

Viewed from yet another anglo, Poland's fate seems

1. Buel1, Raymond LesI10, Europe, p. $19 \mathrm{~V}$

2. Dybosk1, Roman, Op. Cit., p. 16

3. Borman, Isaiah, The Ier Forld, p. 271

4. Temperiey, H. W. V., Op. C1t., Vol. VI, p. 219 
to fall into line with certain wider derelopment. in the Buropean world. Those who hold it as an established truth that since the Reformation Protestant powers in Earope generally adranced in strength and importance, while Catholic netions deoayed, may think of the old Poland as doomed together with Spain, and only affocted more tragically than spain itself, bocause much lese favorably situated on the map. But oren those who do not believe in Protestantism as an -lixir vital for nationo, will be inelined to think that poland perishod, among other reasons boceuse she did not make the best eithor of Protestantism or catholiciam. ${ }^{1}$

Poland tood aside in the great religions ware of the serenteenth contury, then lapsed into paseivity whioh made her a preg for forelgn natione. Her inactirity in the great wars of the eighteonth oontury and her consequent sufferinge, were from that point of vier but eymptoms of venishing prestige: irresolute religious toleranoe was followed by the pacifism of paralgsis.

But ourely Poland's attitude--whatever it was-on the great religious issue of early modern times was not in itself a suffioient canse for the overthrow

I. Dyboge1, Roman, Op. CIt., pp. 16-II 
of what was then a vast monarohy of great international power, rich resources, and a high degreo ol oulture.

Should wo then, find the seed of Poland'a dissolution in the very process of her territorial growth? That growth indeed, has cortain peculiarities which have an orident bearing on Poland's extraordinary fate.

An examination of the territorial growth of Poland and its later decay, shows that the impediments surrounding the construction of the Pollsh-Iithuenian monarchy on all sides were indeed too great to allow its complete realisation and continued safe existence. The rival power of the Hapsburg dynesty and sweden, the nending preoccupation with the Diet, the extraordinary growth of Russia, and Inally, the German barrier on the Baltic, fixed since the oarly uiddle Ages, all these combining, would have taxed the strength of a state much larger, richer, and more Iirmly sottlod in its internal conditions than the Polish-It thuanian ompire ever became through the four centuries of its united existence. 1

Wo pass to a more intensire review of Polish history during the period of the partitions. 
Frederick II was not on friendly terms with most of his neighbors. But he determined to oultirate the friendship of Catherine II of Russie and he aleo aided her in bringing to the racant Polish throne her former lover, Stanislang poniatowski.

Lt catherine's request, Frederiok sent prussian troops into Poland and shortly before the election of the Polish king, signod a treaty with catherine in which she secured all the adrantages of the treaty for herself, Froderick promising to interfere in Poland for the eake of purely Rassian interests. It was hinted however, that in case of war he might hope for componsation.

By a now treaty with Rugsia, 1767, Frederiok agreed that ander certain circumstances, he would throw an army into Austrian territory; but, in such a esse, he fully intended to compensate himself at the cost of Poland. ${ }^{2}$

Froderick recognized the danger of an Austro-Russian war in whioh Pras8ia mast fight for Rassia with doubtful prospects of compensation, the certainty that catherine meant to absorb Iurkish territory, and that Joseph II of Lustria and raunits, his minister, were determined to

1. Honderson, Ernest $\%$., $\leq$ short History oI Germany. pp. 206-209 
have compensation, to break up the Rus80-Prussian Alliance if possible, and abstitate a Russo-instrian undertaking in 1ts plaoe. Intrigue sharpened every faculty of Froderick's mind and in this great game of otrategy and chlcanery he had the more level head, the more experienced hand, and a definite and limited object - the acquiaition of west prussia.

He held right to bis alliance with cathorine and when Joseph of Anstria in 1770 seized the Polish district of zips to satisfy an old olaim, he flung h1s troop into Elbing. On January 28, 1772, the necret treaty with Russia riveted catherine and Frederiok in an agreomont to partition Poland, and there was nothing for Joseph to do but to fight Prassie and Rugeia, or join the agreement on the best terms he covld make. War, as Frederick hod forseen, was unnecessary if the three despots of eastern Europe would aggrandize themselves at the expense of a defense1088 neighbor.

By the treaty of Pobruary 19, 1778, Latria joined in, and after five months opent in setting details the partition was an accomplishod fact. ${ }^{1}$ a previous agreemont between Prussia and Russia had been made in

1. Iewingk1-Corwin, Bdgar H., The Politioal H1storY of Poland. p. 311 
St. Petersburg on February 6, 1778. Joseph acquired Galicia and Lodomeria, Catherine large strip of I1thuania, and Frederick, Fest Prussia, with Pomerellen and Ermeland, but without Dansig or Thorn. on September 13, the proclamation of annexation was made. 1

Frederiok II had boen the chief instigator of the first partition. Bg this partition Poland lost one-third of her territory, bat the great fortresses of Daneig and Thorn, very much coveted by Frederick, remained in the possession of Poland. Three jeare later (1775) the poles accepted a revised constitution which, though making for more orderly and more economical administration, left Poland entirely dependent apon Russia. But when in 1788 Russis bocame involved in war both with qurkey and Sweden, the ant1-Russian party among the poles led by Adem Cosimer cartorasi and Ignatius Potock1, seized the opportunity of electing alet pledged to secure a liberal and independent constitution for their unhappy country. The Diot, which mot at Warsaw in Ootober, 1788, lasted four years, secured the withdrawal of Russian troops and entered into cordial relations with Frederiok Filliam II of Prassia. The latter readily conoluded an offensiro

1. Marriot, J. A. R. and Robertson, C. Grant, the Evolution of Prussia, p. 152 
and defensive alliance with the Poles, and offered to recover for them Anstrian Galicia, provided theg were willing to hand over Dangig and Thorn to him. But while they procrastinated, Prussia and sustria came to terms at Relchenbach and Poland had lost its chence. Norerthele8s, the Polieh patriots made a desperate effort to put what remained of their house in order.

In 1791 a new constitution 1nspired by British practice and the Prench Rerolution was adopted that gave prospects of making the country strong and upitod. It represented a sincere effort to convert the country into a constitutional monarchy. The elective monarchy, the liberum reto, and the right of confederation were swept away; the execut1ve wes rested in a hereditary king, assisted by responsible ministry; there was to be a bi-cameral legislatare, including representatives of the citles; the oaste system was abolished and large installment of social reform was effected. 1

The adoption of this model constitution came as a surprise to Earope. The new constitution was an act of defiance to catherine, who was pledged to maintain

1. Buell, Raymond Ioslle, Poland, p. 41 
the enarchy enshrined in the constitution of 1775. The other partitioners, however, looked more kindly upon 1t. To Austria, Polend strongthened and renovated would have been on undoubted adrantage. Frederick Filliam of Prussia cordially congratalated the Poles on the Constitution of 1791 .

In 1798 the situation was again in several ways more favorable to Rusaia, not least by rosson of the fact that the Austrians were involrod in war with France. With Anstria out of the field, Russia no longer feared Prussia, consequently a emall group of pre-Russian Poles formed the Confederetion of Targowica, denounoed the ner constitution as despotic, and demanded their anclent liberties. When they eppealed to catherine for help, only too willingly Catherine complied. 4 Russian force was sent into Poland and before the end of June Poland was once more in the grip of Russia.

The noteble reforms devised in 1791 were swept aray, the old archaic constitution was restored, and Catherine, despite a strong protest from Austria, took toll from her Polish friende in the shape of som 98,000 square miles of territory and three million

1. Buell, Raymond LeBI10, Op. CIt., p. 48-49 
poople. Pruseia, admitted to a share of the spoll, got Dandig and Thorn with the provinces of Great Poland, Gnesen, Kelisch, and Posen, including in all about a million and half of people and 22,000 square miles of territory. ${ }^{1}$ The partitioners promised to $\mathrm{use}$ their good offlces to secure the Bavarian exchange for Austria, a concession which did little to plesse the emperor. Austria, however, was deeply engaged in the west, and her protests against the second partition could therefore be safely disregarded.

The Polish patriots did ererything in their power to avert the $108 \mathrm{~s}$ of another part of their country. but they otruggled in vain, and on September 23, 1793, the Diet at Grodno gave silent assent to the cession of Posen, Danzig, and Thorn to Prussia, and at the same time reroked ell the proceedings of 1791 and entered into formal alliance with Russia. Is a crime against the principles of nationality and independence the partition of 1793 was even worse then that of 1772. The two really responsible partitioners, Frederick of Prussia and Catherine of Ruseia, might in 1772 have sensibly pleaded that poland had shown herself incapable of reform; that, as she

1. Marriott, J. A. R., and Robertson, C. Grant, Op. C1t., p. 187 
then stood, she was a perpetual menace to the security of her neighbore and to the peace of Europe, and that Pruseis and Russia were merely recovering lands which in the past poland had taken from them.

But no similar plea could arail to excuse the partition of 1793. The Poles had manifested not merely the desire but the ability to set their house in order. In the eyes of the partitioners the crime of the reformere of 1791 was that they did their work too well; that they might have given a new and vigorous Iife to Poland and thus have interposed a fatel and final barrier to the aggressions of her powerfal neighbora. 1

The Polish patriots did not aoquiesoe tamely in the second dismemberment. After it had been consummated in 1793, the Russians were virtually in military ocoupation of what atill remained of independent Poland.

In Narch, 1794, howerer, the Polish army rose under thoir former leader Tadensz rosciusko. This raliant hero after the partition of 1793 had undertaken mission to Paris. He returnod to Poland, colled upon his countrymon to throw off the yoke of Russia and Prussia,

1. Marriott, J. A. R. and kobertson, C. Grant, Op. C1t., p. 188 
and expelled the Ruesian garrison from Cracow, Warsan, and V11ne. For some months Kosciugko was practically master of Poland; but his triumph was short lired. In May, 1794, Frederick W1lliam placed himself at the head of a Proseian army and marched into poland. In June the Prassians won a decisire victory at Rawka. The Russians then inflicted a crushing defeat upon Koscinsko. Kosciusko's defeat was soon followed by the extinetion of his country.

In January, 1795, Catherine II came to secret arrangement with the Emperor, to which Prassia was to be subsequently intited to adhere. The Russian Irontier was adranced up to the river Bug, and an adition of territory which brought with it about 1,200,000 inhabitants was made, Austrie obtained Cracow with the Palatinates of sandomir and Iubelsk, with about $1,000,000$ peoplo. Prusala was to have Narsen with the district between the oder, the Bug, and the Mlemen, but only on condition that she acquiesoed in further accesion of territory both to Rusgia and Lutria at the expense of Tarkey.

Frederick william was highly indignant, as woll he might be at the treatment accorded to him by Russia. ${ }^{1}$ 
18 things were he had no option but to acquiesce in the terms offered to him, and so in 1795, Her East Prussia was added to his dominions with another million of Polea. The partitioners thus destroyed the Polish State; they did not and could not, howerer, destroy or exterminate the Polish nation.

The partitioners' actions and especially Frederick's actions in the firet partition have been defended; first, because poland was a djing kingdon whioh the surgery of partition restored to a ner 11 fe in the march of Prussian civilization and progress; second, becanse the partitioners had taken back territory which had once been their own and again, because the Prussian acquisitions were reclaimod with marvellous labor, and had conferred on it the blessings of an enlightened autocracy and an efficient administration; fourth, because if Frederick had not interfered, Catherine and Joseph would have made the partitions, and Frederick would have obtained nothing; fifth, because the geographical, political, and military neods of prussia required that the gap between Fast Prussia and Prussian Pomerania should be fillod in; and lastly, because without the annexation, Prussia could never have played the part in German and European 
history that she has subsequently played to the Indisputable benefit of Germany, Europe, and herself. ${ }^{1}$

These arguments are simply illuminated angles and variants of the contral doctrine that onds justify moans and that reason of atate and law of dynastic needs baoked by bayonets are enperior to all other considerations. They would apply to and justify ang and every aggressive conquest. The partitions were and remain a crim.

This bringe us to the consideration of the question of how far Poland's internel conditions contributed to the deoay of her political power and to her fingl undoing. It is on this great problem that the opinions of historians and scholars are most sharply divided, and stand out most glaringly against each othor.

Poland had a fully dereloped parliamentary syatem, while the monarchies which dismembered her were more or less absolute. Hence the verdict of some modernists that Poland's parliamentary institutions were too far adranoed for the age, and Poland perished as a martyr

\footnotetext{
I. Larriott, J. A. R. and Robertson, C; Grant, op. Cit., pp. 158-53

8. IbId.. p. 153
} 
for progregeive ideas to be realized generally only in a somowhet later period. This interpretation 1s opposed to the older doctrine of the so-colled "Cracon school" of historians, a doctrine dominant in Polish scholarship for a long time, and largely consonent with the views of forelgn -- especially German -- students of Polish history.

locording to this doctrine -. which had its origin in the depreseed mood of the nation after the fallure of the insurreotion of 1868, Poland fell from internal weakness and not from outside interference; had sho deserved to live Europe would have prevented the partitions by some concerted effort; her past was only a sham greatnese covered with a tinsel of glorg that copeealed the rotten core; there was no possible future for such a nation. ${ }^{1}$ The old poland brought her catastrophe upon herself through 111 use made of parliamentary libertios: Ireodom degenerating into 11cense, the rights of the individual being unduly extolled and his duty to the state neglected, all attempts at administrative or social reform baffled by this archaic Individualism and by the clase egoism of the nobility and gentry.

1. Humphroy, Grace, Poland the Unexplored, pp. 320-21 
Poland perishod through lack of a strong central government authority, and ensuing lack of enforcoment in all matters vital to the life of the state -justice, finanoe, military organization, and consistency in foreign policy.

This fatalistic view which certainly had a large body of facts in Polish history to support it, suffered Irom limitations proper to all such general theories; it often orerlooked positive achierements, or minimized their relative importance, which in some casen only became apparent in our own daye.

To combine great measure of popular liberty with the necessary strength of central state authority seems today next to impossible. Yot this was the task which Poland faced at the time when her territorial growth and international prestige were at their height, and her politioel and moral responsibilities accordingly the gravest and the greatest.

We have examined now in a brief eurrey, the possible causer of old Poland's decay and fall and som explanations of her mysterious survival after politioal death, and wo arrive at the deop truth, that the forces of the epirit are the true sources of life. 
Nerer extinguished in the social organism of Poland, and more active than ever in the last otages of her material decay, they were to tide that nation acrose the dark abjes of captivity and subjection into a renewed fullnese of existence in a later period. 


\section{CHAPTER II}

FROM THE PARTITIONS TO THE PEACE CONFERIMCE 


\section{CHAPIER II}

FROM THE PARTITIOHS TO THE PEACE CONFEREICE

The century and more of Poland's division between her three neighboring empires and of the government of the nation by foreign rulers might at preaent, with Poland reunited and free, eppear to be but a dark Interval which it would be best to pass nnnoticed in gurveging the history of Poland with regard to ita bearings on the present.

Yet the century during which modern Poland was deprived of unity and freodom, was no other than tho Great nineteenth century, the ere of the growth of democracy, of gigantic achievements in science and technology, of the awakening of nations long submerged In darkness and tyranny, and of the developments in smpire-building, and in international trade whioh led up to the greatest convulsion and revolution in recorded history.

The record of the nineteenth century Poland was one of cesseless, untiring, and active resistance to forelgn domination by every possible mons and on erery occasion which the course of international affalro seemed to offer. Hence the reputation which the Poles in the nineteenth century acquired all over Furope of 
being the most persistent and the most romantic military adventurers in the world. ${ }^{1}$ Thue, for twenty jears they followed Napoleon's eagles and shed their blood on all his battle fields in the unflagging hope that out of his drastic rearrangement of the map of Europe new and complete Poland would ultimatels arise, and the spirit of those yeara did bear fruit again and again.

Wherever a netion struggled for liberty, Polish knighte-errant were sure to be found on its front ranks.

In the nineteenth century, the partial and halfhearted concessions by which the partitioning powers at various times mot the insatiable desire of the poles for complete political froedom did not hinder the nation, through tro-thirds of the nineteenth century, from rising in rebollion again and again.

Two insurrectionary wars against Russia, in 1830-31 and 1863-64, each taxed Russia's huge military strength to the utmost; and the "epringtime of notions" in 1848, sweoping the whole of Europe with guste of revolutionary morements, had 1ts stormy reverberations both in the Austrian and the German division of Poland. 
If, however, the canse of poland falled to recelve active sppport Irom Western European Powers at critical and crucial moments, the risings, neverthelese, achieved one end: They kept the Polieh isene alive in Europe's international politios, and did not allow it to sink to the insignificance of merelg 1008l and provincial metter.

Poland's greatest poot, Adam Ulokiewics, writing for the comfort and pleasure of his fellow exiles in paris book of parables, admonitions, and propheofes in Biblical prose, odlled the Books of the Polloh Iation and of the Polish P1lgrimage (1833), had ended 1t with a Pilgrims' Iitany containing prayer to God, "for a great war which would bring deliveranoe to oppressed nations." ${ }^{2}$ and, indeed, as the nineteenth century was drawing towards its close, it seemed that little short of the terrible fulfillment of Mickieriog' inspired prayer could bring the Polish canes back to 1ife. Forty years after polend's last armed rising, the Polish problem, as an issue of international politice, seemed thoroughlg dead and buried. France, which had often manifested a sympathetic and friendy interest in Polish national aspirations, 
now, efter her defeat of 1870-71, had sought security in an ellianoe with Tsarist Ruseia, which Impliod the tacit abandonment of the largest section of Poland to Russien oppression. Austria, which for cogent reasons had allowed self-government to its Poles, was drifting into greater dependence on her powerful Germen elly. Germany, herself, wes as determined as ever to supprese Polish nationality within her borders. Her endeavors in that respect went exactly parallel to Rusela's and it seemed that wheterer other differences might arise between them, Berlin and st. Petersburgh would almays see alike on the question of Poland.

In Poland 1tself, not only had the interests of the three divisions of the country come to direrge widely from each other, but the generation growing up since the last armod etruggle of 1863, had become too absorbed in the pursuit of the material ends of modern economic effort to retain a vivid sense of the reality of national aims.

The land-owning gentry, which had been the backbone of resistance to forelgn rale in previous uprisinge, now profeseed acquiescence, and actually erolved political programme of reconolilation and threefold 
loyalty; even under Prussia, where it was engaged in struggle for the land, that class never thought of any bat logal weapons in the contest.

The manufacturing and comercial communties in all three sections, but particularly under Rassia, had excellent reasons to cling to the connection with largo imporial organismo.

The peasantry, for the most part nationally nnawakened, always essentially conservative, and now bent with might and main upon the aoquisition of more and more land, naturally could not be expected to puraue what seemed the chimera of national reunion and fresdom.

Under the ofroumstances it was only the professional intelligentsia of the town -- that class of determining importance for all spiritual movemente in latter-day continental Europe -- which kept the toroh of national aspirations burning. ${ }^{1}$

In epite of all preparatory activities, the declaration of war in sugast, 1914, opened up for the Poles a gloomy and agonizing prospect. They saw themelves herded together in the ranks of the German. Austrian, and Russian armies, about to be harled againat

1. Dgrosk1, Roman, Op. CIt., D. 11 
each other in fratricidal strife, brother pitted against brother, and both against thoir mother oountry. Four years of variod horror followed. Four years of invasions and counter-invasions, of armies moving back and forth and systemetically ravaging or robbing as they moved; four years of terrible isolation from all Iriends and four years of ignorance of what was goinc on in the outside world.

What hope was there for the poles in such a war? What could they see but continued subjection to others? If the Central powers should win, Rusaia might be compelled to give up her Poles, but who would get them, if not the Austrians and the Germans? If Austria and Germany should 108e, would not the outcome be merely the reverse, subjection to Russia instead of to Austria and Germany?

To be sure, throughout the war, the one side or the other tried, as its fortunes waned or waxed for the moment, to lure the poles to hearty cooperation against ito enemies by promising them restored and united Poland in the end, but these promises were alwaye vague and floeting, always qualified by some ambiguity or reservation that rendered them null, or nearly so, in the eyes of the poles whose experience in the past 
with the triple bank of oppressors did not lead them to repose an unlimited confidence in them nor.

But unanimous as was the opinion of the pablio generally regarding the jugtice of the Polish cause among etatesmen and politicians, the idea was scarcely less general that from a practical standpoint the cause was hopeless. The only hope for the Poles in the great war was that both sides, Russia on the one hand, and Germany and Austria on the other, should come out of it defeated. But such a hope could not be reasonably entertained, so preposterous it soomed. Hevertheless, the preposterous happened.

Russia was defeated by the Central Powers and was compelled to sign the treaty of Brest-Iitorsk. The Central powers were defeated by the Allies and compelled to eign the Verseilles and other troatios. The ground was cleared for new structure, and one more substantial and more comfortable for 1to occupante than that whose uncertein and shadowy plan had, during the war, been dangled before them at various times by thoir oppressors.

It was, howerer, the Russian Revolution which was to exercise a decisive influence on the counsels of the Allies and on the destinies of poland: It did so 
oven in 1ts first stege, while it still seemed that changes would be moderate and Ruseia would hold out in the ranks of the Allies. The Provisional Government of the revolutionary period issued on March 30, 1917 , a manifesto to the Polish nation, recognising its right to politioal indopendence. 1 Although this contained an allusion to somo sort of union between the ner Poland and Russia. It was justly hailed by Poligh opinion as a highly important and further step in the diroction of deliverance. 2 \& beginning had been made by Russia herself with thorough readjustment of ageold relations establishod by conquest.

Even before the menifesto of revolutionary Ruseia, the volce of America, a power still noutral at that time, but soon to be a determining factor in the European struggle, had rung out elearly on the subject of Poland. President w1lson, in a mesage to Congress foreshadowing America's possible share In the conclusion of the peace, had doclared that a reanited and freo Poland was one of the war aims admitted on all aides. 3

It was also before the Raseian manifesto that

\footnotetext{
1. Dyboek1, Roman, Op. CIt., p. 16

2. Fisher, H. H., Merica and the Hew Poland, p. 96

8. George, Devid IIOya, Lemoirs of the PeQ0e Conferenoe, p. 680
} 
M. Dmowal had submitted to Balfour a momoir embodying his own and his fellow workers' ideas on the territorial composition of a reconstructed Polish State -- 1deas which essentielly remained his programm when he afterwarda represented poland at the Peace Conference.

It was, on the other hand, under the encouraging impression produced by President Wilson's utterances and by revolutionery Rusia's recognition of Polish claims that the sustrian poles on their part, now ventured to state national aima more frankly than had ever been done before in the Central Empire. resolution passed by the Austro-Polish parliamentary Deputies assembled at Cracow in May 1917, expressiy defined a complete and independent poland as the goal of national aspirations. It was also in this resolution that sustria was for the first time treated by her Polish subjects not 28 a protecting Porer, but as an Aly, whose services were only wolcome if helpful for the attainment of the clearly defined national aime. That such an unprecedented note should have been struck, was rendered possible not only by the turn which affairs had taken in Russia, but also by a recent happening under the Austro-German occupation. The 
question of draving upon the occupied territory of former Russian Poland for recruits was becoming an acute one for the Central Powers. It was cautiously proposed to widen the framework of Piloudski's Legions (Poles organized by Joseph Pilsudski to aid Austria) so as to create a larger Polish armed force which, however, would at the same time be more unreservedly at the disposal of the Contral Powers for their war aims.

Pilsudski, at this critical point, parted company with the Central Powers to whom he had alwajs professed only conditional allegiance. He forbede his loyal followers to take the new military osth required of them and refused it himself. His faithful legionaries were disbanded and interned and he himself imprisoned in the fortress of Magdeburg. Thie imprisonment added considerably to his prestige in the ejos of the nation; it raised him to the dignity of a aymbol of national resistance to foreign raje. 1

France now at last saw her way to authorize and assist the formation of a Polish army for the Allied side, and hortly before the close of the War on 
Jaly 8, 1918, Poland was raised by a docieion of the Allied statesmen at Versallies to the rank of a belligerent Allied nation. The Polish rational Comittee in paris was thereby recognized in the Allied camp as an offlolal representation of the polish people.

While the war yet raged, long before the Peace Conference opened, the problem of Poland had boen onvisaged from a very different anglo by the slifes to that of the Partitioning Powers.

48 early as uy, 1917, as wo hare observed, the attitude of the Poles themselves was defined by the Polish members of the Anstrian Parliament who declared that "the desire of the Pollah nation was to have restored an independent and unitod Poland with access to the sea." ${ }^{2}$

Hore 1mportant, becanse it had more foros behind 1t, was the opinion of the Entente Powers, Whose timldity in this matter, 28 in many others, hed been pronounced but wa now beginning to catch up with the poseibilitios and requiremente of the situation. Rugsia's western Allies had alwaye observed diplometic silence on the polish question, 1. Hoker, H. H., Op. CIt., p. IOI 
and consored all unofficial allugions to 1t. In 1916, Italy was the first among the lliled Powers to raise its roice in behalf of the free Poland. On November 15, 1916, the Csar of all Rase1a himself, announced his intention of establishing Poland, including Russian Poland, Galicia and Posnenia, as an antonomous and united kingdom within the Russian Ampire.

On January 6, 1918, David Iloyd George, stating that he was speaking "for the nation and Empire as a whole," declared that "an independent Poland, compriaing all those genuinely Polish elements who desire to form part of 1t, is an urgent nocoseity for the stability of Western Europe. $n^{8}$

But, perhaps, the best and clearest statement of the aspirations and determination of the alliod and Associated nations at war was given by Woodrow Wilson in an addrese to a joint session of congress on Jenuary 8, 1918. In this discourse, the President onunciated his famous "Fourteon Points." The thirteenth point stated that, "An independent polish state hould be ereoted which should inolude the territories inhabited by indisputably Polish

1. Hoher, H. H., Op. C1t., p. 96

8. George, Darid IIoyd, Op. Cit., Vol. II, p. 630 
popplations, which should be assured e free and secure access to the sea, and whose politicol and oconomic and territorial integritg should be guaranteed by international covenant." ${ }^{l}$ sereral times throughout the year of 1918, President Filson reiterated in one form or another the main views expressed in this program.

In the two months between the midale of september and the midale of November, 1918, the two Bmpirea which, B1noe 1915, had held all the Polish lands, topplod in defeat and revolution.

The events and negotiations whioh signaled the defeat of the central powers and their recognition of Polieh independence may now be briefly onumerated. On September 15, 1918, the Government of the Dual Monarchy asked the President of the United states for a statement of terms of perce. On Ootober 4, the nemly appolnted German Imperiel Chancellor, Prince Max of Baden, proposed the conolusion of a general armistice. In his note, Prince max requested the President of the united states to take steps relative to the restoration of peace, to notify all belligerents of the request, and to invite them to delegate plenipotentiaries for

1. Seymour, Charles, Op. Clt., V01. IV, p. 800 
the purpose of taking up negotiations.

The note further stated that the German Gorernmont accopted as a basis for the posce negotiations, the program laid down by the President of the United States in his meseage to Congrese of January 8, 1918 , and in his subsequent pronouncements, particularly in his addrese of september 27, 1918. In order to avoid further blood shed, the German Government requested the President to bring about the immediate conolusion of general armistioe on land, on water, and in the air. ${ }^{2}$

The note also stated that the German Government believed that the governments of the powers assoclated with the United States I1kewise accepted the position taken by President Wilson in his address.

We may thus observe thot Germany and Austria Hungarg agreed to the resurrection of the independent poland with e free and secure access to the sea, in her preliminary negotiations for an armistice.

The poles interpreted these requests for an ermistice on Wilson's terms as recognition of their Independence and proceeded to set up their own temporary government in the place of those of the 1. HEher, $\mathrm{H} \cdot \mathrm{H} \cdot$, Op. CIt, P. II 
Central Powers.

On October 8, the Regeney Connell at Warsan issued a manifesto dissolving the council of state that had been elected under German anspices and prepared to sumon a popularly elected diet as the Constitutional Assembly. About the same time the anthority which the Contral powers had exercised since 1915 in the Congress Kingdom was relinquishod.

On November 3, 1918 at Warsaw, Poland was declared a Republic. No Improvised government set up in Poland was recognized by the Allies, but in paris, the Polish rational committee, which controlled no Pollsh territory, enjoyed Allied recognition as the representatives of the Polish nation. ${ }^{1}$

Fortunately for Poland the German revolution released from the fortress of Magdeburg the man who through the exigenoies of the war had become the most popular leader of the soldiers and the masses of the poople. Joseph Pilsudski arrived in Warsen on November 10, and his arrival marked the beginning of a centralization of authority. On the dag of Pilsudaki's arrival in varsan the Regency Council solemnly declared the German occupation at an end.

1. Hoher, H. H•, Op. CIt, pp. I16-II 
On the day the Axmiatice was signed Pollsh officiels took orer the executive functions in Warsew, and the Regency Counoil placed the supreme military anthority in the honds of P1lsudski. The Regenoy Council did not long survive the German authority which had oreated it, and on Norember 14, it submitted to popular demand and resigned. The Commander in Chief of the arm became Chief of the Polish State.

By thie time the poles were divided into two groups of almost equal strongth, noither of which was willing to submit to the other, nor etrong enough to force its will on the nation. The Pollsh National Committeo in Paris, was hoaded by M. Dmowaki and dominated by the National Democrats. This Committee controlled the Polish Army in France, now commanded by Haller, and it also enjoyed the confidence of the Oreat powers who representatives were gathering in paris to redraw the frontiers of Burope. on the other side, Pllsudak1, the hero of the maser was ingtalled in जarsam. His porsonal prestige with the mesees was greater than that of ang leader on the other side and at his back was an army rapidly growing in numbers and organization and intenselg loyal to him. But P1lsudekl's position was weak where that 
of his rivals was strong. His service in the forces of the Central powers had not been forgotten by the AIIles and more damaging, perhaps at this time, were his socialist opinions and his long revolutionary career. Bolsherism had succeeded Toutonism as the great bogey of Mestern opinion, and Bolsherism was an inclusive term making socialists of all complexions suspects.

Foreign rale had been broken, bat poland was still divided. Dirision meant weakness; union, strength. Weakness and division were not the right kind of wares to display before the all-powerful Allies, who were then assembling at paris to fashion among other thinge a new Polish world. To escape disaster, and to profit by the independence won at such cost as Poland had paid, It was necessary and imperative for the poles to patch up a political unity which would make it poseiblo to utilize the prestige and ability of P1lsudeki in poland and of Dmowek1 and Paderewsk1 in peris. onder these circumstances, a compromise wae made by which the Moraczersk1 cabinet resigned and paderewsil became Premier and Foreign Minister on vanuary 16, 1919, with a cabinet representing the different parties and also the different afvisions.

Paderewski's assumption of Premiership is a 
landmark in the history and restoration of poland. The new state wes able to present a united front at the Peace Conference, which had its first seseion in paris two days after the new cabinet asenmod office, and was represented by her Prime kinister -one of the most notable and influential personalitien at that historical gathering. 


\section{CHAP TER III}

THE PEACE CONFERHMCE 


\section{CHAPTER III}

\section{THE PEACE CONFEREMCE}

The Preaties of Paris constitute the greatest mosaure of national liberation of subject nation erer achieved by any war settlement on record. The Peace settlement meant the bringing of freedom to many milition of poles. It was by no means a simple tagk to determine the borders of the new state. The difficulty of applying the idea of nationality was increased because the boundarles of "historio poland" fluotuated from generation to generation and often included large areas where the population was not polish by race and language.

The Peace Conference summoned the representative of Poland before it on January 18, 1919, and by so dolng formally reoognized the new polish state. poland was given two votes in the Conference. Poland was represented by K. Dmowsk1 and I. J. Paderersk1 with Casimir Dluskl, a P1lsudskl appointeo an an alternate.

Hpwerer, the recognition of the Polioh state did not determine the very important matter of what territory the new state was to oontain. These memories of a Greater poland were destined to give 
trouble to those who sought to settle national boundaries on ethnological and traditional principles. When the Poles presented their olaims to the Conference, their claims were by every canon of self-determination extravagant and inadmisable.

M. Dmowski's conceptions of the reconstruction of Poland were known to the allies from his memorandum addressed to Balfour in 1917. True to h18 pre-wer view that Germany was the most dangerous onemy of Poland, Dmowski laid stress on a maximum of territorial acquisitions on the restern gide of Poland, which would insure Poland's economic and strategical Independence as against Germany. ${ }^{1}$ Not content accordingly with the recovery of the province of the Posnania, lost through the Partitions, he desired to ser Poland'g historicel access to the $8 \theta a$ by Danzig safeguarded through the posseseion of a wide stretch of territory on both banks of the lower Vietula, including if possible, Poland's sometime rassal state, the province of Bast Prusala. He wished to see Poland's economic development in the direction of industrialization placed on a firm basis by the incorporation of silesia, which

1. Buell, Raymond Lesile, Op. C1t., p. 63 
had been separated from Poland since the fourteenth century, and included in Prasela since the middo of the eighteenth century. ${ }^{1}$ on the eastern side. on the other hand, he prepered to sacrifice large portion of the borderland possessions included in Poland before the partitions partly because they were inhabited by non-Polish population which had since reached a troublesome degreo of national consciousness of their own, and partly also because he wished to leave the door open for a future understanding with pussia. 2

y. Dmowski's vievs in this, as on most other points, were fundamentaliy different from those of Jo seph Pilsudski's and his politicel allies who continued to $8 \theta$ in Russia the principal danger to Polend's existenoe.

Plloudsk1 inherited with the blood of the -8etern borderland gentry from whioh ho had aprung, a vivid sense of the great historical tradition of Poland's imperial union with her eastern noighbor, If thuania, and of Poland's civilizing mission in the IIthuanian and Rathenian border countries. Hia

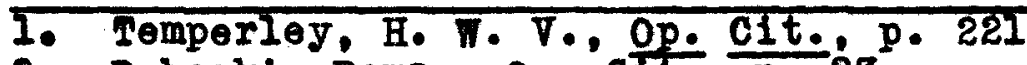

8. Dybosk1, Roman, Op. CIt., p. 83 
programme was, accordingly, more extensive and ambitious on the eastern than on the western 1de. P1lsudski imagined the eastern borderlands constituting a series of small buffer states between Russia and Poland, which would be auperior civilization if Poland gradually could be drawn into some sort of federative union with them.

on the western side he would have remained satisfiod with the restitution of her Polish-German frontier as it existed before the first partition in 1778..$^{2}$ If, now, we compare the settlement actually effected by the Peace preatios with these two different Polish conceptions of it, we observe that the oolution given to the Polish problem by the peacemakers of Versailles was, like their solution of many other European questions, necessarily somowhat hasty and accordingly unsatisfactory. On January 29, 1919, M. Dmowsk1 presented the territorial claims of Poland. In settling the boundaries of Poland, he said Poland would not be satisfied with the historioal boundaries of 1778 in the West. For example, Silesia had been lost to 
Poland since the fourteenth centary, but today ninety per cent of the population, owing to the national revival, had kept its language and was strongly Polish. He remarked thet the whole territory of Fastern Germany was not naturally German but was Germanised. He quoted Bulow as saying that what Germany had lost in the west in the breaking up of Charlemagne's empire, she had gained in the east. Summing up the question of what is, or what is not, Polish territorg, he suggested that a rough definition would be that such territory as had been oppressed by AntiPolish laws was Polish territory. ${ }^{1}$

He went on to say that if the coast belonged to one nation and the land to another, there would be mutual tendencies to conquest, and quoted Herr Bebel as saying that Germany's task was not to colonize Africa, but to colonize the Vistula region. He maintained that it would be more just to expose a small Germanised country to infiltration by Polea, than to deprive all Poland of economic independenoe and to expose it to German eggression. The Conference at paris manifested so car as

1. George, David Iloyd, Op. C1t., p. 632 
the boundary between Germany and Poland was concerned two main tendencier in the discussions according to its official historian.

The firgt tendency was based on the idea that friends should be strengthened at the expense of enemies, and that the innocent should be strengthened at the expense of the guilty. It showed a leaning in all doubtful cases to give the benefit of the doubt to Polend.

The second tendency rested on the principle of doing justice to onomies as well as frienda. On the whole, the second tendenoy in most instances prevalled, $M$ r. Temperley maintains, and especially so in dealing with Danzig and the Polish Corridor. ${ }^{1}$ So far as the frontiers with Germeny were concernod, etrategic considerations were for the most part completely ignored.

It may be added that in regard to regions which had been taken away from Poland by great international wrong and crime and Germanized by unlque and shamefully political mothods, it was nelther unreasonable nor unjust to give poland the benefit of the doubt in

1. Temperleg, H. W. V., Op. CIt., p. 241 
oases where doubt really existed.

In the attempt to secure justice as between nation and nation, it was agreed that nationality must be the chief basis of settlement. It was equally agreed that economic factors might orerride the factor of nationality. History was not and could not be ignored altogether. Religion was taken into account, but mainly in a negative way. The Poles demanded that the ethnographic criterion should be the determining factor, and that where it wes necessery to modify the othnographic frontier because of economic, historical, or other considerations that modification should be to the advantage of Poland. ' They interpreted the ethnographio frontier strictly as including all regions in which Poles by race and language were in majority, and they were inclined to assume that Polish race and language implied in all cases a wish to be united to the now Polish otato.

In addition they went considerably further than the Intente powers in their desire to modify the ethnographic frontier to their own advantage for

1. Temperlej, $\bar{H} \cdot W \cdot \bar{V} \cdot$, Op. CIt., p. 236 
economic and other reasons.

Perhape in certain oeses they asked for more than they really expected to receive and sometimes damaged their position by asking too much.

The deciolons lay with the Peace Conference as a whole, but primarily with the Principal llied and hssoolated Powers, the United states, France, Italy, Japan, and Great Britain. The decisions were in all cases unanimove.

On the central point all the Powers were agreed that it was necessary to establish a Polish state and with it a real chance of existence, that is a state with the greatest possible stability and strength. opinions differed only in the manner in which poland could be made most strong and most stable.

The French aim at the Peace Conference was a peace of security. France was conscious of a German menace which threatened both her and Poland alike. She was not, howerer, unconscious of the difficulties involved nor did she wish to go as far as the poles themselvee. 1

The Commission which the Conference appointed on Polish affairs, headed by M. Jules cambon, Frenchman,

1. Temperleg, H. W. V., Op. CIt., p. 238 
leaned strongly toward the Franco-Polish view on dispated points. In the report which it submitted to the supreme Counoil toward the end of varch, it recommended that Poland be given the greater part of Posen and Upper Silesia, broad corridor to the sea along both banks of the vistula River, and the city of Dansig.

It was indicated in the first report of the Cambon Commiasion that the drawing of a frontier line on a purely ethnological basis was almost an insuperable difficulty. Fconomic and strategic requirements had also to be taken into account in drawing boundaries in order that the new state thus delimited should have a fair chance of surviving. The real cause of the death of Poland, said M. Cambon, was not merely its faulty political organization, but principally its lack of communcation with the sea. The real end of Poland did not come in 1772, but in 1743, when Danzig was 108t. ${ }^{1}$ Without that port Poland could not live. By it alone could poland have access to liberal powers in the west. It was no use setting up a poland deprived of access to the sea, as it would ineritably be the

1. George, David Iloyd, Op. Cit., p. 639 
prey of Germany or of a reconstituted Rusia. poland must have not only a sea-board, but also full and fres communication with Danzig. If he had to choose between protecting German populetions largely imported since the eighteenth centurg, and protecting Poles, he unquestionably preferred the latter alternative.

The American aim at the Peace Conference, a was shaped by her President and rotced in his public addresses was for a peace of fingl world conciliation. He hold up the banner of the ideal.

President wilson was enthosiastioaliy proPolish. In the Peace Conference he oympathized strongly with Polish aspirations. But he told Ray Stannard Baker on April 7 that, "the only real interest of France in Poland is in weakening Germany by giving Poland territory to which she has no right. ${ }^{l}$

American delegates had displayed very early marked interest in the matter of Polish independence, and, like France, had historic ties with Poland. As regards the frontier with Germany, the Americans

1. Baker, Ray Stannard, Hoodrow Hilson and WorId Settlement, Vol. II, p. 60 
were, like the British, consolous of the hasard of including too many Germans in Poland.

In the later stages of the negotiations, the Amerlcans displajed more reluctance before acopting further modiflcations introduced by the Britioh. The British aim lag somewhere between the other two, - practical perco combining conciliation and security, punishing Germany without orushing her, Improving the world, but not seeking all at once to achieve the miliennium. 1

The British were most conscious of the inexpediency of including large numbers of Germens within the polish frontiers and were the prime movere in the direction of diminishing the number of German in the new Polish nation. 2

Llogd George was against Poland annexing ofty of Germans -- againgt it also for the seke of Polend. "We must set up a Poland that can I1ve," he said. "If owollen by enemy populations she will explode from within, Danzig is outside the real orbit of Poland, me it international." President Filson oupported him; M. Clemenceau was persuaded; and Mr. Iloyd George

1. Spender, Harold, the Prime Mnister, p. 291

2. Temperlog, H. W. $\bar{V}$, Op. C1t., P. 239 
got his way.

Mr. Lloyd George wished Poland to flourloh as a self-governing state, but not to enter on its existence by inflicting on others the crime of the Partitions from which it had so deeply suffered. For this reason, in the last stages of the conference, he took a strong solitary stend on the demand for plebicite that orme up for Silesia. The whole British cabinet supported pim, and in the end ho achiered his purpose.

Such were the main lines of agreement and divergence where divergence existed, but it must be otrongly emphasized that only after full discussion of the principle involvod, did the conferenoe arrive at its final docision. 


\section{CHAPTER IV}

WEAT TERRITORY SHOULD POLAND INCLUDE? 


\section{CHAPTER IV}

WHAT TERRITORY SHOUID POLAND INCLUDE?

Why should Poland be restored to life, - and to a position in the galaxy of nations? She had been dead so long, why should the political fabrio of today be disturbed by outting out another nation by very old pattern?

It had been argued with some potency that Poland should be resurrected because the equilibrium of Central Europe would be restored thereby, and a sare and certain basis for a lasting Buropean peace secured! It was alleged that central Europe had been anstable and unbalanced since the disappearance of Poland; again, Poland should be restored to life, said the Allies, because German expansion to the East would be retarded or even stopped, and further, that Poland should be given new lease of existence because it was right. Even the ground cried out againgt the infustices ouffered by poland. Between 1864, the date of the last Polish insurrection, and 1914, Europe as far as possiblo aroided allusion to the skeleton in the oloset; not every state had been guilty of murder, but all had 
known of 1t, and none 1ntervened. When the first gune were fired in 1914, the oloset door was shattered and Poland was found to be alive.gagged.

The main factors which have preserved Poligh consclousnese were: the peasants' attachment to the so11, the peoples' stubborn deciaion to cling to their language, and their faith in God, their ultrareligious spirit.

Poles, they were, and poles they had remained; they had lived through years of religious and nationel persecution on the part of prosia and Prussia, and withstood victoriously sustria's demoralizing poliog of assimilation. Through years of torture, of exile, imprisonment, jears of punishment, year of expropriation for speaking their own language and teaching it to their own children, they have prayed and hoped. The very persecutions of their oppressors made them strong, and during the days of this war these very oppressors had to admit that their policy of foroible assimlation had not only failed, but had had the opposite result from the one they desired. 
011 knew that poland had fought a hundred wars, but not one for conquest. $4 l 1$ of her wars had been in self defense, in defense of justice, of right, or of christianity. In 1241 at the battle of Iignia, she threw back the rartar Invaders, and thereby saved Germany. In 1683, John Sobieski saved Europe from the ottoman dominion. The Polish Rerolution of 1794 prevented the coelition of the autocrats from accomplishing the defest of France. Through five centuries Poland bore the brunt of Turkish arme, until she mon the appelation of "the Buckler of Christendom."

She has warred often for the liberty of others. poland has been the cradle of the world's liberaliam. She conoluded in 1413, a political union with Iithuania, an act of free union proolaiming for the first time in a document of almost erangelical beauty, the brotherhood of man. ${ }^{2}$ she was the first to provide that, unless legally convioted, no man should be imprisoned.

In 1808, Poland first applied the elective Pranchise, the Polish statute of wislica. In 1573

\footnotetext{
1. Gorsk1, Waclaw D., "The Aspirations of Poland," Out1001,120, pp. 628-31, September-December, 1918
} 
Poland Inaugarated a virtual repablio; ite chief magiotrate was elected for life, and called a king but forbidden to lead the militio acrose the frontiers except with the consent of the senate: And in that very same year, the year of st. Bartholomev's night, the Polish senate provided freedom for all creeds, the right of every man within its juriediction to worship as he chose.

The Polish executives, the kinge, were limited in thoir power by on excessively liberal constitution. They were lacking in authority while the nation was deprived of a permanent standing army, and thus an easg preg to their rapacious neighbora; her fertilo plains known in ancient times os the granary of Europe, afforded them an added temptation. ${ }^{1}$

The friendy democratic Entente nationa: the United States, England, and Franoe favored the restoration of Poland to $11 f e$ and gave her again a chance to hold aloft once more the torch of liberalism and to become a bulwark against Bolshevike and the Germans.

und last, but not least, from 25,000,000 to 36,000,000 poles, speaking the Polish langrage, in

\footnotetext{
1. Gorgl, Waclaw D., "The Asplrations of Poland," outloor,120, pp. 628-31, September-December, 1918
} 
every decade of history wanted Poland restored. The poles regarded themselves as the ohosen people, chosen not for Jictory, but for suffering. "Polend was the Keseiah among the nations, by whose broken body and shed blood salvation was to be wrought for all the nations of the rorld. ${ }^{l}$ as the partition of Poland had been the greatest crime of the old regime, so her resurrection was to usher in new era of peace. From 1770, when a outle plague efforded an excuse for the invasions by foreignere, until poland was restored to a position among the self-governing nations of the earth by the treaty of Versallien, there were alwags efforts being made by some of the poles to throw off the yoke pleced on them by the Russians, the Austrians, and the Pruseians. But granted that Poland was to be restored and should be restored and to be given e free and secure accese to the sea, what was poland? What territory should it have included and what were its proper boundaries? What criterion should be used in determining its boundaries? Should the boundarles be linguiatic, cultural, oconomio, geographic, or hiatorical? poland had been erased from the map so

1. Temperley, H. W. V., Op. C1t, p. 234 
long that it had come to be regarded as a name, a memory, a cause rather than a country.

Now it is clear that the most elementary justice demended the setting up of a polish atate with some reasonable chance of life, nor was any other alternative possible to the Peace Conference, oven if it had been desired.

In determining the territorial allotment of Poland, the Peace conference considered firat the principle of viability, that is, that a state must have resources, size, and access to markets to enable it to aroid economic ahipwreok. ${ }^{2}$

In the second place, there had been general agreement on the wilson postulate that the new Polish state must (1) include territories inhabited by indisputably Polish populations, (2) be assured - Iree and secure accoss to the sea, and (3) be guaranteed political and economic independence and territoriel integrity. As interpreted by the Polish leaders, this meant a return to the bounderies of the eighteenth century. 3

1. Hagking, Charles Homer and Lord, Robert Howard, Op. C1t., p. 156

2. Bowman, Isaiah, The New World, p. 410

3. Ib1d., p. 410 
Mang even wished to see Bast Prussia included. It was taken for granted that Danzig would become - Polish port. All of eastern Galacia was assumed to be Polish territory, though inhebited largels by Ruthenians. All of Upper Silesia was considered eseential, in order thet the vast resources of that region might be available for rebuilding of Poland's Industrial Iife.

On the northeast lay If thuenia, and the Polea could not forget that it was once part of the greater Poland with a long Baltic coast line. Ilke other states of central Burope in post-war years of chaos and uncertainty in both domestic and foreign affaire, Poland feared her nelghbors and felt that the more extensive her territory and larger her population, the greater would be her future security

Goographically, Poland is one of the hardest countries in the world to define. Clearly marked natural frontiers are oomowhat lacking or else, when they can be discerned they do not colnoide with the historic political boundaries or with present ethnoGraphic boundaries. The cerpathians for instance, seem to offer an admirable natural frontier on the

1. Bowman, Isq1ah, op. C1t., pp. 4II-412 
south; neverthelese, the boundaries of the old Polish otate overlapped this mountain range for a considerable distance, and so does the polioh Iinguistic frontior today.

on the north, the Baltic should form the netural limit of Poland, but historically Poland hed seldom erer held more than narrow frontago upon that soa, and today the area of Poliah-speaking population touches the Baltic only along a short stretch of cosst, the region of the so-called "Polish Corridor," the subjeot of this study. on the east and west no natural barriera whatever are to be found in the vast unbroken plain which stretches across northern Europe from the Iow Countries to the Urals and acrose Asia to the pacific. 1 It is true that Polish geographers are accustomed to treat the whole region between the Baltic, the Carpathians, the Drina, and the Dnieper as oountry; to claim for it a high degree of physical unity wh th respect to its structure, climate, productions, river ojetems, and other features; and to argue that this ontire area ought likewise to form a political unit, poland. Goographic poland thus defined is practically

1. Haskins, Charles Homer and Iord, Robert Howard, Op. C1t.. p. 157 
identical with historical poland as it was in 1 to later periods. 1

Ethnographic Poland includes nearly the whole of the so-called "Congress Kingdom" of Poland, most of the former Prussien provinoe of Posen, parts of the Prussian provinces of East and West Prussia and Silesia, and the restern part of Galicia. 2

In adition, there are many Polish enclaves scattered about in Eastern Galioia and in the Russian provinces to the east of the Congrese Kingaom. There is much reason to suppose, horever, that if ever an honest census is taken here, the eastern limits of the Polish ethnographic area would be extended considerably beyond the boundaries of the Congress Kingdom. Historically the name "Poland" has been applied to state with rery widely fluctuating frontiers. 3

The hundred years of Russien rule sinoe the Partitions and violent attempts at Russification have by no means destrojed, al though they have in part

\footnotetext{
1. Haskins, Charles Homer and Lord, Robert Howard, Op. Cit., pp. 157-58

2. Ibid., p. 158

3. Ib1d.. p. 159
} 
nullified the results of four conturies of polonization in the eastern territories, Bven today in It thuania proper and in large areas of white Ruseis and the western Ukraine, the country gentry and the non-Jewish population of the town. are predominantly Poligh. ${ }^{1}$

It would probably be true that the average pole has, at the back of his head, the foeling that his country is not merely the modest area of ethnographic Poland, but the whole wide expanse of historic Poland; Poland as it was in 1778, just before the partitions. Phis conception is besed partly upon the principle that the partitions, as lawless acts of usurpations, could have no legal validity, so that real poland still exista within her frontiers of 1772; partly upon the vier that the Iands between the Carpathians, the Balt10, the Dnfeper, and the Dvine possess so high a degree of geographical, oconomic, and cultural unity that they deserve to be considered as one country.

The wide dispersion of the Polish race, the divergence between what is ethnically Polish today, and whot was historically, and still is in part

I. HaskIne, CharIes Hoiner and Lord, RObert Howara, Op. C1t., p. 163 
culturally, Polish, the lack of adequate data as to the othnic make and political gravitation of so many of the border populations, the lack of clear cut, netural frontiers, such are some of the difficulties in the way of defining Poland's proper boundaries or in deciding what is Poland or what territory Poland should include.

We now pass to more specific consideration of the so-called polloh corridor, the creation of the Peace Conference of paris for the parpose of giving Poland a safe and secure outlet to the sea.

1. Haskins, Charles Homer and Iord, Robert Howard, Op. Cit., p. 170 


\section{CHAPTER V}

\section{THE POIISH CORRIDOR}




\section{CHAPTER V}

THZ POLISH CORRIDOR

The wedge-shaped sector of land called the Poliah Corridor runs inland from the Baltic Sea for aistance of 45 miles acrose territory which at the close of the World War was a part of the German Fmpire. At the coast it is merely 20 mile wide, increasing in width to $60 \mathrm{mlles}$ at the conter and 160 miles at the extreme south.

Goographically, the limits of the corridor are hard to fix, for the eimple reason that the German. themselves have never set a definite limit to the territory which they claim as the corridor. In practice, however, it is generally understood to include the present Polish province of pomerelia and the Netze district belonging to the adjointing province of posen, that is, the territory taken by Prussia in the first partition of Poland, together with the district now included in the Denzig Free State. Thus delimited, it has an area roughly oqual to that of Massachusetts and Connecticut combined, and population of somewhat less than million and a half. 
Historioally, the region of the corridor has been the battle ground of slev and renton for more than seven conturies. The struggle began when a Polish Duke of Masovia invited the Teutonic Knights to establish themselves on the east benk of the Viotula River and to undertake the task of conquering and converting the pagan Prassians who were troubling his borders. This was in the year 1225 and during the next hundred years the reutonio Knights established themselves in all the region between the Nieman and Viatula Rivers. Their capital was at Marienburg on the Nogat. Onoe ostablishod, however, the Teutonic order waged war equally with Polo and Pruselan. The latter were presently either assimilated or annihilated, and thousands of colonists were brought from south Germany to settle this wilderness.

In the fourteenth century, the order crossed the Vistula and repeated its exploits. Here again, conquest was followed by colonization. Hênceforth. therefore, the population on this left bank of the Vistula was mixed, While Danzig became what it has always remained, a purely Teutonic town. In the fifteenth century, the Poles deferted the Teutonio 
Inighte at Tannenberg, on the same fleld where Ifve hundred jears later Von Hindenburg won his great victory over the Russians.

Thereafter, the disintegration of the order was rapid and the Second Treaty of Thorn in 1466 not only restored the west bank of the Vistula to Poland, along with Danzig, but traneformed the Grand Master of the order into a vases of the Polish throne for the East Prussian Duchy.

In the eighteenth contury, Frederiok the Great found himself possessed of this Prussion Duchy which had passed to the Blector of Brandenburg, and had thus escaped from Pollsh suzerainty, but was still separated from his other dominions by the Polish Corridor, ereoted by the preaty of Thorn.

To abolish this Corridor and establish territorial unity for his kingdom, he ongineered the firet partition of Poland.

The Second and Third Partitions extended Prassian holdings of Polish territory, and even Napoleon -great friend as he was supposed to be to the poles -in oreating his shortlived Grand Duchy of Waraaw, refrained from restoring the corridor. Finally the Congrese of vienna confirmed Prussian title to the 
Corridor which now became West Prussia, and titio to posen as well, and this condition endured thereafter until the close of the morld war.

From an historical standpoint, the Poles base their claim to the corridor upon original possession and three centuries of undisturbed occupancy between 1466, the date of signing the second Treaty of Thorn, and 1772, the time of the first partition of Poland. The Germans rest their olaim and titlo to the corridor upon the conquest and colonization by the reutonie Knights and upon the century and a half of possesetion between 1772, the time of the first partition, and 1919 which is the date of the signing of the Treaty of Versailles.

Ethnicelly, the situation a respects the corridor is even more intricate as a consequence of the long centuries of intermingling. That the territory was originally inhabited by Slavs before the advent of the Teutonic Order now seems certain. That before the World War, Fast Prussia was largely Germanised and West Prussie partially, is equally true.

In 1919, that 18, at the moment of the making of the Treaty of Versailles, the situation was confueed; in fact, all depended upon the area chosen for 
a test. Thus in the whole province of Prussia and the Hetse distriet, there was an undoubted German majority. In the region actualiy taken from Germany, that 18, the Corridor and the Dangig Free state, while the margin we much narrower, the German adrantage was still probably conclusive. on the other hand, in the area actually transferred to Poland, the Slave, quite as certainly, outnumbered the reutons. But even here, the German olaim, with justice, that not all the slars are Poles, and with far lese warrant, that the cassubiane, living in the ruchola Heath and farther north cannot be fairly oredited to their rivels.

These claims and counter claims remein somewhat hazy and uncertain beoanse they are based on the German side on Prussian statistios whioh were notoriousiy partial, and no plebiscite was ever conducted.

The Poler had an indecisive majority according to Prussian statiotics. On the ove of the world war there were 990,000 inhabitante. 437,412 were Germane, 448,773 were Poles and 104,000 were Cashubes, a peoplo affiliated olosely with the Poler, ethnographioally opeaking.

Moreover, Poland maintained that the ethnographio 
principle could not be followed too minutelg, because the corridor was the scene of intensive conoentration by Germen colonista aided by the Prussian government. The German Imperial colonisation Commission in thirty years, spent $600,000,000$ marks in buying ap property in the eastern provinces and eetting German coloniste upon it, thus disposeessing the Poles of a land which had been theirs for a thougand jears.

Helf a dozen other offiolal and semi-official organizations have been at work for the same purpose. Over 100,000 Germans have been brought in in this way. In addition, host of government funotionaries and servante estimated to be from one-fifth to onethird of the German population have been brought in from the onteide for the parpose of impressing an artificlal German character upon a Polish land. ${ }^{1}$

The substantial preference which the German farmer onjoyed gradually forced out Polish settlers. It is difficult for eren the Germans to deny these patent facts.

The absence of a rote was explained by Wilson's decision to bestow upon Poland access to the sea over

1. Heskins, Cherles Homer and Lord, Robert Howgrd, Op. Cit., pp. 174-75 
her own territory. To give effect to this decision involred restoring the Corridor as it had existed before the First partition. President wilson's decision was based upon the obvious fact that the new Poland would have an area greater than that of Italy and a population in excess of Spain, and Fithout free access to the sea, this large area and its great population would be economicalig at the mercy of Germany, which would hold its natural sea gates. President wilson, too, was profoundy influenced by what he concelved to be the moral 1ssues involved in undoing the work of the Partitioners.

But the case of Poland is unique, moreover, in that it has an othnic group of indisputable Polish poople, straight through to the ses. ${ }^{1}$ This was the first and the principal reason for the establishment of this now famous Polish Corridor by the Peace Conference. Poland needed territorial access to the sea. No one would seriously diepate that. But it is doubtful that the Peace Conference would have granted her an outlet to the sea where it

1. Heskins, Charles Homer and Iord, Robert Howard, Op. C1t., p. 178 
was granted had the Conference not been justified in its opinion in doing so on ethnographic, es well as historical and economic grounds.

Thus there existed at the time the treaty was made, on the west bank of the Vistula River an unbroken corridor of Poligh-speaking territory extending through well nigh to the sea. The Germans have never bridged successfully this gap between the old German lands in the West and the isolated German oolong in Fest Prussia.

Apparently. Wisdom and justice guided the hands that created the Polish corridor. If there had been any good way around it, it might have been an undesirable arrangement. It seemed the only solution to the problem that had any ethnographic reasons for its creation. We shell later observe some suggestion thet have been proposed for a different outlet to the sea for Poland. But each of these proposals has as many or more obfections as hes the present outlet. The solution merely restores the territorial eituation that existed here for three handred years down to the time of the First partition in 1772. Hor can the continuity of German territory be mainteined without denying Poland access to the ser. 
In reality, what we now call the Polish Corridor appears today to have been in some fashion a German dam stretehed across the Pomeranian plains, holding back the slav tide from the age of Froderick the Great to that of W1lliam II. But once the dam had been abollabed by the Treaty of Versailles, the Slav tidel wave swept down the corridor to the sea in a vast and irresistible drive which has all but wiped out the last vestiges of German construction as today there is a great preponderance of poles in this region.

Poland was given then a minimum direct access to the sea. The Polish Corridor was intended to promote farorable commercial contacts between poland and the industrial and commercial centers of Western Europe. Post war developments have made this irreducible minimum of access even more vital to Poland then ever before. Placed between a Communist Russie with whom normal trade is impossible and a Germany who will not buy what Poland has to offer, Poland has been compelled to reorient the direction of her entire foreign trade. The main currents of that trade no longer run between the east and west, but from south to north. 
Polish imports and exports follow the Vistula river and show a tendency to derelop towards the Baltic notions and the great Western Powers, 1. e., Fngland, France, Italy and the United States, by virtue of her sea cosst and the possibility of communication by sea. Poland is a quasi nelghbor of these countries, whereas, according to the thesis suggested by German propaganda, she should be only a state shut in by the territories of Germany and Russia. Britain has become an important purchaser of Poland's agricultural produce, the Scandanarian countries of her corl, and more distant oversea lands buy in increasing quantities what cannot be sold to Poland's continental neighbors. Poland once more, as in the sixteenth century, mst be a Baltic Power, or not be at all. one has then to face the simple fact that here are two netions, one of $65,000,000$ (more now in view of recent annexation), the other of 32,000,000 facing each other over a more or less imaginary line, motually resolved to carry out purposes which are irreconcilable. They are actually engeged upon this front in a struggle which differs from real war only in the fact that it is conducted, not by armies, 
but by all the forces of publio opinion and propaganda. What is most disturbing is that this atraggle steadily inflames public feeling, exaoerbates national passion, promotes despair. But the trouble with the situation is that there can be no answer as long as Burope and the world remain dominated by nationalistio sentiments. For the problem of the Pollsh Corridor there are two solutions: German and a Polish, but there is no disposition to compromise at present. Poland insiste upon retaining an outlet to the sea over her own land, while Germeny refuses to endure the isolation of Bast Prussia from the Reich. Fithout disoussing more fully such purely domestic German problems, it must plainly be stated that, in the last resort, the issue lies between greater or lese economic inoonvenience for one German province on the one hand, and the existence or non-existence of the entire thirtytwo million Polish state on the other.

Poland can point to her historical experience in the partition period which showed that the ennexation of her sea-side lande by Pruseia at the second partition in 1793 meant the outting of the jugular artery of her political-economic organism. Under the existing 
Circumstances, German communication with East Praseia by land is at the mercy of Poland save for treaty guaranty; after revision, Polish access to the sea would be at the mercy of Germany.

In this situation it 18 clear that questions of economic right, race, language and history are relatirely ubordinate. Yet, both the Germans and poles can fortify their claims by such details.

The Polish state as it exists today, combines in Its larger balk a number of requirements for an existence economically sound as rell as politically independent. ${ }^{2}$ But it was this very creation of a "greater Polend" which not only entangled the new republic in ineritable conflicts with almost all her neighbors, but also called forth remonstrances from among the western Buropean authors of her restoration.

There were writers and publicists of standing and renown who frequently expressed the opinion that it was a mistake that Poland wes re-establishod in somowhat like her wide oighteenth-century frontiers, which once already had been the cause of international complications and of disaster to the country. Whon the treaty was still in draft General Smate 
76.

of South Africa warned the Paris Conference that

it had made Poland too strong for the peace of

Europe, and adrised its curtallment as a measure

of precaution while there was still time.

- L letter of General J. J. C. Smuts to the

Prime Minister, Iloyd George, May 22, 1919, critioized

the terms as drawn and anggested changes.

Mag 22, 1919

The Prime Minister

In re Germeng' Bestern Frontier

I am convinced that in the undue enlargement of Poland we are not only reversing the verdict of history, but committing a cardinal error in policy which history will yet avenge. The new Poland will include millions of Germans and Russians and territories which have a Germen or Russian population, or whioh have for very long periods been part of Germeny or Russia. It is reasonably cortain that both Germany and Russia will again be great powers, and that sandwiched between them the ner poland could only be a success with their good will. How, under these circumstances, can we expect Poland to be other then a failure, oren if she had that ruling and administratire copecity which history has proved that the has not? Even now while the conference is sitting, the Poles are defying the Great Powers. What is going to happen in the 
Iature with the Great Powers divided and at loggerheads? I think we are bullding a house of send. Ind in view of these and many other considerations, I rould revise the boundarles of Poland as provisionally settled in the Treaty, leave Upper Silesis and all real German territory to Germany, contract the boundaries of the Freo City of Dansig, and inatead of placing her ander the suzerainty of Poland as we propose doing leave her under the eugerainty of Germany with an administration under the Ieagne of retions. I think the two cardinal errors in policy of this treaty are the long occupation of the Rhine, and the enlargement of Poland beyond anything which wo had contemplated during the war. These two errors are full of menace for the future peace of Burope, and I urge that every moans be taken to remove them before it is too 1ate. There is no doubt that the German Delegates are going to make atiff fight, perhaps a condition for signature of the Ireaty. that the settlement of their Fastern Prontiers in silesia, Bast and Nest Prus81a, should be revised. I would advise that we consider the oase to be put forward by them more carefuliy on its merits.

$$
\text { J. C. Smutal }
$$

The danger which General Smuts polnted out had

been anticipated more than serenty years before by

otto Von Biamark, who saw further than most statesmon of his century. As early as 1848, long before he

1. Barer, Ray Stannard, hoodron hilson and WorId Settlement, Vol. III, Document No, $6 \overline{6, p p \cdot 458-465}$ 
ontered official life, Bismark accurately prodicted the territorial ambitions in which Poland would indulge if it were ever to be reconstituted with the province of Posen as a jumping-board. Then, he wrote, "She would not rest until it had reconquered from us the vistula mouth and every Polish village in West and Fast Pruseia, Pomerania, and sileaia." ${ }^{1}$ Germang cennot become reconclied to the 1086 of several large provinoes into which, aince sho took them from Poland, she has put great amount of organizing effort and also of capital.

It appears that the corridor is too narrow to be sucoessfully defended against Germeny or other bordering enemies both in the east and the west. ${ }^{2}$ It was the wish and hope of the Poligh loaders at the Peace Conferenoe, that they would be given broader stretch of land than that occupiod indisputably by Poliah populationa.

Their hope was based upon the relation of the Polish State to the Vistule River. For the relation of the viotula River to all Poland is that of the

\footnotetext{
1. Daw8on, WIIIam Harbutt, Germeny Under the Ireatr, P. 387

2. Buell, Raymond Ie8I10, Op. Cit., pp. 320-321
} 
Lis81881ppi River to the great central region of the United States. Since the earliest time this river has been associated with Polish nationality. They have inhabited its plaing for ages. From the Carpathian Mountains to the Sea, its banks have long been bordered by Polish populations. They hare possessed its shores, even if the soverelgnty of the river belonged to someone else.

Poland derived economic as well as cultural and poychologioal strength from the vistule in higher degree than, for instance, Germany does from the Rhine, the source and mouth of which are outside of German territory, and the upper parts of which constitutes the boundary line between Germeny and Switzerland, and Germany and France. The Vietala is in fact, the backbone of Poland, her old capital, Cracow, her new oapital, Warsaw, and once her only port, Danzig, are all situated on the banks of the vistula.

The arrangement of the corridor has been denounced by the oritics of the Treaty of Versaliles on the ground that th1s Corridor cute off Germany from their East Pruesian Province, and that it is something that the Germans will never stand for permanently. 
It is alleged that the isolation of Bast Prossia effected by the Poace Treaty is unnatural, unique in the modern world, and ruinous to the province so separated from the body of Germany. As against this, it must be emphasized that similar "Corridors" are not unknown elsewhere; the canadian "Corridor" to Vancourer, to mention only the instanos most familiar to British and Amerioan readers, has never been an obstacle to the development of Alask as part of the United States, nor as a cause of enmity has it ever come between the two nations.

With regard to Bast Prussia, it is a woll established fact that German transit across the Corridor, as safeguarded by international conventiono and often checked both by official authorities and private foreign observers, ${ }^{1}$ was facilitated in every way, and poland has never declined to discues further extensions of these facilities. But it is pleaded that East Prusgia has suffered gravely in her economio I1f through her detachment, and a morement of omigrations from that province into the interior of Germany has actually set in. The German budget is burdened with large expenditure on "relief to the East." which as a matter of fact was largely uged for the

1. Hagkins, Charles Homer and Lord, Robert Howard, Op. Cit., p. 180 
political ond of promoting and otrengthening Germanism along the Polish border.

The complainte regarding the economic sitration of East Prussia are not altogether unfounded, but are certainly exaggerated. The conditions, desoribed as effects of the isolation of the province, are part of the general economic situation of Germany which is due to grest many factors other than the territorial settlement. Ther are also part of the economic relations of commercial diffidenoe or open "tariff war" now unfortunately so general between European States. It is Bast Prussia whioh atands in the way of favorable trade treaties with Poland the agrarian clase-interest of her large landownere -- a thoroughly reactionary and fanatically notionalist group -- being allowed to carry undue weight in the councils of Germany's rulers. Should a million and a half or two million of Germans have rights that outweigh $27,000,000$ to 32,000,000 poles in the Hinterland to a secure access

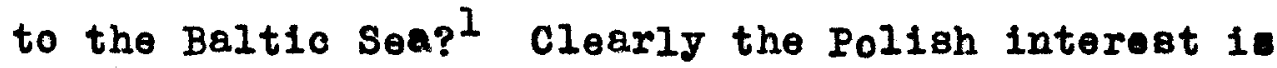
incomparably the greater and ought to take precedenco.

1. Hesring, Charles Homer and Lord, Robert Howard, Op. C1t., p. 180 
Therefore, very properly, the conference oreated the "Corridor" for the access of Poland to the sea. Poland once agein, 2 in the eighteenth century, may be an obstacle in the way of German aspirationa, and if Germeny so strongly resents the existence of the Polish corridor, it is certainly not only becanse the Corridor cats off Best Prusgia from Germeny, bat because it is a barrier between Germany and Russia. What Germany wants to effect by the removal of the Polish corridor is the creation of new and much broader "Corridor" over the head of Poland, uniting Germeny with Russia. The small Baltic states, particularly Iithuania, would then serre but as a continuation of a German "Corridor" so conceived. It is plain, then, that it is not against the Polish Corridor as it exists today, but against Polish corridor, in faot, against any and every corridor to the Baltic that the efforts of Germeny are and will be directed.

It would be dangerons to the whole European system for Germany and Ruseia to be so closely united. If this danger is to be arolded, the maintenence of not only Poland as a mole, but of her outstretched territorial arm to the sea, appears 
to be a truly wise and far sighted Furopoen policy. If Poland and Europe are to bo safe and remoin safe, the Baltic must become neither a German nor Russian nor Rasso-German lake, but remein a Buropean and a world lake.

The corridor was constructed at a moment when the prinoiple of nationality dominated any other consideration. Whether one judges according to the principles establishod by the Verseilles Treaty, or according to some personal standard, there is one polnt upon which all have agreed: as a result of the interdependence of nations so generally discused today, no corridor can remain trouble maker for Poles and Germans alone. Danger of war between two nations is a danger of war to the world. This is a very good reason everyone should be interested in the solution of this international problem. Suggested alternatives to the corridor may be mentioned to show how unacceptable they are for Poland. The absorption of the corridor together with Danzig and East Prussia into the body of reunited Germany could, it is said, be compensated to poland by the right to use all northeastern 
German harbors from stettin to Konigaberg. But those who have a knowledge of present day international conditions must realize that any guaranteos which oould be given for the inviolability of suoh commercial "rights of way" are worthless in a Burope deprived of a strong international executive. ${ }^{1}$ The same objection is made to the 1 dea of erecting Dansig together with the Corridor, and possibly Bast Prussia, into a noutral political unit under international administration. The "Pree City" of Danzig alone has caused more than onough trouble to the League of Nations in the last twelve yeara; a larger territory under international control in that part of the world would prove much more unmanageablo and would only be source of constant quarrels and anxieties.2

There is a third proposal which has boen tentatively broached and is favored by some British statesmon. It proposes to return the corridor and the access to the sea at Danzig to Germany, in return for whioh, Poland should receive access to the aea further east, by way of Memel, through territory

1. Dybosk1, Roman, Op. C1t.. p. 399

2. Ibid.. p. 399 
which is now German. But this would oanse a violent, unnatural and entirely impraoticable twist to Poland's whole gystem of communioations by 45 degrees, twist that is wasteful and diffioult becanse the portions of the country that noed a direct outlet to the sea such as the silesian coal fields would be then farthest amay from the outlet to the 8ea. Then too, the Memel plan would involve thorough ohange in Poland's relation With Iithuania, the re-establishment in fact, of the hidorical union between the two countries. ${ }^{2}$ Iithuania, at present, shrinks at the thought of a renewal of the unfon, because she fears that in such a union her national distinctness would be endangered through weight of numbers and through Polish oultural influence.

The paris Peace conferenoe saw it to make most complicated and artificial arrangement for Poland's outlet to the sea. It took Danzig from Germany but did not give it to Poland. Howerer, the control of the corridor to the sea would be of iftle or no advantage without the control of 1te natural terminus, the port of Dansig. Danzig is

I. Dybosk1, Roman, Op. C1t., p. 400 
the ond of the Corridor, the port of entry and the port of exit for the vistula River, the great river of Poland. Danzig had belonged to the former Polish state and had greatly prospered as all the ocean commerce of the country had passed through 1ts harbor. Pruseia had acquired it in 1793 in the Socond Partition, and as late as 1813, the City Council of Danzig besought the Powers of Europe to reunite Danzig to Poland and not to incorporate it with Prussia.' Very prosperous and contented ander Polish rule, Danzis largely lost its prosperity ander the Germans. The Poles, because they regarded the city as rightfully theirs and also because it was their only outlet to the sea, expeoted that it would be Included in the new state.

The so-called "Cambon" Commission, the Commission appointed by the Conference to make boundary recommendations, decided on two occasions after impartial local investigation that panzig should be unconditionaly alloted to Poland. That it was not, was due to the opposition of Lloyd George, with whom President Wilson was persuaded to agree, Clemenceau aoquiescing, though untillinglg.

1. Hegkins, Charles Homer and Lord, Robert Howerd, Op. C1t., p. 181 
The reason for not giving Danzig to the poles was that Danzig and the region around about, with a population of about 350,000 , was overwhelmingly German in stock, speech and sympathy, thus it was undesirable to incorporate into Poland so large body of persons who would necesearily be a discontented and therefore a weakening element in the now state. The reason is not impressive coming from men who lapsed easily from the principle here involved in their settlement of other questions that came before them. Three hundred thousand Germans of the sustrian Tyrol were handed over to Italy on strategic grounds and three million to czecho-slovakia on historical grounds. The same argumenta might have boen made or applied to Danzig with greater force from the point of vier of Polish national deference and with equal force from that of historioal right.

Although Germang had accepted President Filson's fourteen pointe, the German delegation protested againgt the proposal which would give Poland access to the sea, and insisted that the sea cosst, Danzig, and the mouth of the Vistula River, should remain in Gorman hands.

The German protest was rejected in the well-known 
lotter of Clemencean. President of the Peace

Conference, dated June 16, 1919, and in the enclosed note:

"The reply of the 111 ied and Associated Powers to the observations of the German Delegation on the Conditions of peace. 1

"Poland will be given certain economio rights in Dansig and the ofty itself hes been severed from Germany because in no other way was it possible to provide for that free and seoure access to the sea which Germany has promiaed to concede.

"The German counter-proposals -- deny secure accese to the sea to a nation of over thirty-two million people, whose nationals are in the majority all the way to the coest, in order to maintain territorial connection between Fast and west Prussia, whose trade has always been mainly sea borne. They cannot, therefore, be accepted by the Allied and Associated Powers."

The relevant pageages in the Allies' reply read 88 follows: "Section IX -- East Prussia -- for Poland -. For Poland to have immediate and unbroken communication With Dansig and the remainder of the coast by railways

1. S10wgki, Dr. Stanislaw, Poland'g Accesg to the Seg, p. 5 
which are entirely under the control of the Polioh state is essential. The inoonvenience caused to Bast Prussia by the new frontier is netigible compared to that which would be caused to Poland by any other arrangement.

"Section XI, Denzig, -- The economio intereste of Danzig and Poland ere identical. For Danzig a the great part of the valley of the viatula, the most intimate connection with Poland is essential. The annexation of West Prussia, including Danzig. to Germany, deprived Polend of that direct 00008 to the sea which was hers by right. The Allied and Associated Powers propose that this direct ac0ess shall be reatored.

"It is not enough that Poland should be allowed the use of German ports; the coast, short as it is, which is Polish, must be restored to her. Poland claims, and justly ola1ms that the control and development of the port which is her sole opening to the sea shall be in her hands and that the communications betweon it and Poland shall not be subjected to any foreign control, so thet in this, one of the most important aspects of national 11fe, Poland should be put on an equality with the other states 
of Europe. $n^{1}$

A clause in Artiole 89 provides that Poland should Guarantee free transit between Germany and Fast Prusaia. In accordance with this provision and in execution of Articlo 98 of the Treaty of Versailles, a Pollah-German Convention was conoluded in paris on April 21, 1921. The eald convention came into force as from June 1922, and is being oarried out by Poland to the complete satisfaction of Germany's transport and economio neede. Poland's access to the sea, in a geographical and territoriel sense, is formed by the Polloh coastal territory.

The principal stipalations of the Treaty of Verseilles and the paris Convention concluded between Poland and Danzig and dated November 9, 1920 are the following:

(a) Danzig is a Hreo City nader the protection of the League of Nations.

(b) Dansig is included in the Polish frontier, in so far as customs and duties are concerned. (c) Poland conducts Danzig's forelgn relations. (d) The railway system and its control are given to Poland.

1. Slowsi, Dr. Stanislaw, Op. CIt., p.6 
(e) Poland has the right to establish in the port poetal, telegraphic, and telephonic communication with Poland on the one hand and with foreign countries on the other. (f) Besides the above mentioned convention. the juridical basis of the Free City of Danzig is to be found in its constitution, elaborated in conjunction with the High Commissioner of the League of Nations, who permanently holds office in Danzig, and who, in the first instance arbitrates in all disputes which may arise botween Poland and the Free City of Danzig. (g) The Polish minority in Danzig shall enfoy the same protection as national minorities onjoy in Poland. (h) The exploration and management of the port, that part of the Vistula which flows through the territory of Danzig, the canals and immovable property formerly belonging to Germany and Prussia, come under the administration of a mixed governing body consisting of representatives of Poland and of Danzig, 1. $0 .$, "the Harbor and Waterways Board." At 
the head of this Board are a Polish Commissioner who represents the Polish Government on the one side, and a Danzig Commissioner, representing the Free City, on the other. The Harbor Board must guarantee to Poland the free use and service of the port and means of Communication, stipalated in Article 20, without any restriction. (1) The Constitution roted by the constitrent Assembly of Danzig in May 1920 was accepted and adopted by the Council of the League of Natione after certain modifioations had been made. Aocording to this constitution the Free city is governed by the Senate which is vested with executive power.

Seven senstors are elected every four jears by the Lower Chamber, while the other fourteen are parliamentary sonators. In 1922 a new constitution was approved by the Ieague. The Senate consisted of ten members conteining a president and vico-president. In order that a statute may become law, both the Senate and the chamber must agree. The chamber now consists of 72 deputier. 1

1. Slowgk1, Dr. Stan18IaT, Op. CIt., p. 9 
The Free City of Danzig did not come into existence from the time of the ratifioation of the Preaty of Versailles but only by virtue of an additional declaration dated 0ctober 27, 1920, made by Rngland, Frenoe, Italy and Japan, on the otrength of Artiole 102 of the Proaty of Versailles. Aocordingly the Free city of Dangig came into existenoe on Hovember 15, 1920, and simultaneouely the Polish-Dansig Convention, which embodies the prinoipal Polieh laws concerning the ocoese to the sea through the territory of the Pree City of Dansig, came into offect.

The only reason why Dansig was detached from Germany and made a Free City was the desire to secure freo access to the sea for Poland. The fact that the original decision was to assign Danzig to Poland is authentic proof of this desire. Dansis is infinitely more alive and prosperous today than she was before the war, when Hamburg orershadowed her. This Baltic trade accomplished within a fow short years, could now be reversed only at the cost of complete economic ruin, and consequently of political destruction, to the entire fabric of the 
now Polish state. It is an axiom of Polish public opinion regardless of the party, that unimpeded accese to the Baltio is a fundamental condition of Poland's continued existenco.

In accordance with the Treaty of Verseilles, Poland received coestal territory without a port, as woll as cortain rights in the port of Danzig without territory. owing to the fact that poland is only part owner of Danzig port and that we has to copo with great difficulties connected with the complicated adminiatrative system of the port, she has seon fit to build with the assistance of Frenoh capital, her own port at Gdynia. Of which fact, the Germens constantly complained to the League of Nations and to othere that the now port is and will be an everlasting menaco to Danzig's prosperity.

The compelling reason for building this new sea port at Gdyaia for Poland was due to the persistent disloyalty of Danzig to Poland, to her constant erasions of treaty obligations, her organized encouragement of muggling on a large scale, and her enmity to Polish interest. I Because of the deadiook in economic

1. Dybosk1, Roman, Op. C1t., p. 398 
relations w1 th Germany, it was necessary that the sea-born trade of Poland should be forcibly dereloped. It soon was very erident that Poland had onough trade to make Gdynia and Danzig prosperou. and in 1933 poland agreed that $45 \%$ of 1 ts imports and exports should pass through Danzig.

It is a favorite Polish atory that in 1920 Herr Sohm who is now Lord wayor of Berlin, bat who was at that time President of the Danzig Senate, had, after refusing to let the Poles import arme for their Ruseian nar in 1920, derisively told them to build their orm port on the quick sands of the Ilshing village of Gdynia. So they did. By 1926 Gdynia ras able to function and in 1932 its harbor traffic reachod and passed the Danzig level. In 1936 it handled more commerce than any other city on the Baltic 808.1 with the help of French capital, a railway was built from the kattomitz coal mine up to Gdynia, and the coal traffic easily direrted from Dans $18 \cdot 2$

The location chosen by the Government for the

1. Wolle, Henry C., "The Ghost of the Corridor," Iow Republic, 92:240, 1937

2. Fiskemann, Elizabeth, "Poland and Germany Today," Fortnightiy, 144 (NS 138): 304-13 S. 1935 
erection of the port is ideal; it is located on the Bay of puck, a bay which could hold all the naries of the world today. The depth of the bay near the shore is thirty to sixty feet, the bed of the harbor is very good for anohorage and tho ontrance is sheltered by the Pehinsula of Hel. 111 foreign experts have agreed thet Gdynia is by nature fitted for a port.

Does Poland really need a port of her own? Does she need to own in fee simple her own sea board? Does she need or require special righte in Dansig? Could she not use some of the other ports of Germany also? Is not Gdynia sufficient for hor neede? Lre there not many countries which do not possess sea cossts or ports and yet manage to exist very well? Poland does and no doubt wants to use some German ports. She is directing a considerable part of her exports and imports through stettin and Konigsberg becauee of their communicational and geographical location and position.

As owner of the port of Gdynia and part owner of a port at Denzig, Poland can also be a oustomer in the ports of Stettin and Konigsberg. But Poland'B noods cannot be satisfied by the use of German ports. 
Folther can Poland's existence nor her politicel and economic independence be so reconciled. Polend could not develop her navigation and forelgn trade out of German ports to the degree she could from her own ports, for there would be the German shipbuilder, forwarding agent, importer and exporter, who would step in as a middleman between the foreign merchant and the Polish producer or importer.

Germany may want Polish commerce to depend on Germany's caprice and whims. Germany would be ablo to fix her own port tariffe, and more important still, her own railway tariffs; Poland would be compelled to pay the tribute imposed, as Germany would have a monopols in this respect. If Poland encounters diffculties in the small port of Danzig in obtaining her right of free access to the sea, it may easily be forseen that, in apite of all agreements, powerful Germang would soon reduce that access to naught. The Germen counter proposel of June 1919 to the Versailles treaty read, in part, that Germany was prepared to declare the ports of Memel, Konlgeberg, and Danzig as freo ports, and to give Poland far reaching rights in these ports. Poland would be then a client of German ports. 
Some netions have no sea coest. of the approximately sixty independent countries of the world, only a very small number have no acoess to the sea on account of their geographical position.

In America there are nineteen countries which are situated on the Atlantic or the paoific 0coans. This farorable position of these countries is the source of their prosperity. Only Bolivia and paraguay of the south imerican countries lack sea coast. In Africa, only Abyssinia, and in Asia, Afghanistan, -- the buffer state betwoen India. Porsio, and Russia Iurkestan, have no sea coast.

Before the war Europe had three countrie lacking a sea cosst; two of these were of small gize and unimportant. The third, Luxemburg, was up to 1914 dependent on Germany with regard to customs and railway anion, and is now united to Belgium, using her ports in accordance with Artiolo Forty of the Treaty of Versailles.

It seems, then, that a seaport owned in foe oimple is indispensable to a nation as large as Poland. 
CHNPTER VI

GERMAN - POIISH RELATIONS SINCE THE WAR 
CHAPTER VI

GERUAN - POLISH REIATIONS SINCE THE WAR

Poland's position on the of contemporary Burope makes Poland's foreign policy far more decioive than wo were accustomed to realize. The principal aim of the polish forelgn polioy was, on the one hand, to maintain so far as poseiblo frlendly relations with her two mighty nelghbore, Germany and Russia, and on the other, to make poland strong against any attack. It should be remembered also, that the Franco-Polish igreoment conoluded January 19, 1921 as woll as the RoumantanPollah Alliance are still in existence. ${ }^{l}$

Poland's forelgn policier were based on the simple formula that Poland could rely on no nation but herself. Colonel Beck, Polend's Foreign Minister, looked with distrust upon the Ieague of rations, the promises of the Western democracies and the mult1lateral security pacts. He had no faith waterer in the word of the Nasis.

and now what is the attitude of Germany toward Poland looking to the future? We all know she hes Contemporary Revien, Januery 1939, p. 62 
armed at a terrific pace. Prodiglous numbers of armod mon have been opringing up where the dragon's teoth weire sown. What was it all for? There was no doubt that German diplomacy wiahed to make the Peace Treatios evergwhere seom intolerable, and that it will epeak more loudly and lese legally when becked by the Iull Army, Navy, and Lir Forces now under construction. Wherever the status quo seems ralnerable there the opponente of Hitler have reason to be afraid. 1

18 to Poland's relation with Germeng since 1919 it might be said that Germany has been brought up on h1story as it was taught in the Bismarckion school with the idea that an independent Poland would be a calamity. The Germens could not believe in the permanence of the etate of things that oame into boing in 1919 on their eastern frontiers. Most of the loaders of the Feimar Republio thought of the new Poland as an accident and spoke of her as a "temporarg" state. One of the main objectires of the policy launohed at Rapello was to make that temporary period as brief as possible. On assuming the ambassadorship to the Soriet Union in 1922 , Fortnightig Reviow, 144 (NS. 138): 304-313 
Count Von Brockdorfe-Rantsan roicod the opinion that nit might be possible to repair at Mosoor the damage that had been done at Versallles."

The Weimer Republic strove to prevent the consolidation of Poland in every way possible. It was always arousing prejudice and opinion against Poland abroad and causing as much trouble to her as it could at homo. That tactio undoubtedly worried Poland, but it did not affect her firm resolve to stand her ground. In another direction it actually mas a help to Poland. It stimulated her business men to take adrantage of her outlet to the sea, hastening the construction of the port of Gaynia by 1930 with French oapital. As the ancient bond between Germany and Polend were severed, Poland's oconomic and politioal indopendence was more and more emphressed.

In a letter to the Crown Prince dated september 7, 1925, Stresemann oategorically declared that "reotification of the eastern frontiers of the Reioh, recovery of the Polish Corridor and of Danzig, and alterations in the boundary lines of upper silesianl

1. Stresemann, Gustav, His Diaries, Letters, \& Papers, V01. II, p. 508 
were outstending items in the list of Germany's territorial demands. In 1931 Chancellor Bruning began applying himself to the execution of that program. He sounded out Paris, London and Rome to see juet how far territorial revision at the expense of poland could be made acceptable to those capitals. ${ }^{l}$

As the fear of Germany increased, the Polish Alliances weakened and Poland began a searching consideration of her foreign policy.

Chancellor Hitler's regime in Germany was received with marked reserve in Poland. The Poled could not guess how he rould set about giving offect to the first point in his platform whioh colled for the "re-entry of all Germans into the bosom of Greater Germany."

The advent of Hitler resulted in e now ant1Polloh agitation in Danzige Polish soldiers guarding the military base at Westerplatte in Danzig were reinforced on the nights of Merch 5 and $6,1933$. Hitler saw that poland would not tolerate any surprise seizure of Danzig, or of any other place, Strong," Forelgn Affairs, Julg 1939 
and that she would give an energetio answer to any German move that affected the status quo. Ho began to place a halt on the irritations that had 1solated Germany and began to try to create healthier atmosphere in German-Polish relations. Speaking at Konigsberg on May 27, 1933, Hitler declared that, "Hational socialism renounces those policies aiming at a modification of natural frontiers at the expense of other people." Marshal Pilsudak1 was the first statesman to forecast correctly the rising powers of the ner Germany and the significance of the razi morement. He Ieared that neither France nor Britain could be counted on to mantain the treaty structure of Versallles by force of arms.

On Januery 26, 1934, without consulting his French ally, Pilsudski negotiated the famons nonaggression agreement with Hitler. The two countries expressed their determination to "base their mutaal relatione on the principles contained in the paot of paris of August 27, 1928 ... both governments deolared that it was their intention to reach direct underetanding on problems concerning their mutual relations ... In no case, however, shall they 
have recourse to force in order to settle such questions under diepute."

The declaration was to remein in force during a period of ten years, but if neither government gave notice of ite termination six months before or after this period of time, it was to continue in erfect. ${ }^{1}$

By this move Gormany made the first dent in the French Alliance system, removed the danger of attack by Poland, secured a shield from Russian eggreseion, and was able to concentrate its forces against Austria. The German-Polish non-aggresition paot onded German 18olation.

By this agreement, Poland was recognized a a great power. Having demonstrated its independence of France, it now became an object of solicitation by many European powers.

The agreement dispelled the bitterness which had existed between Poland and the German Republic. The German campalgn for revision of the Polish frontier, the Polish-German tariff war, and the support hitherto given by Germany to the minorities within Polond came

1. Weeler-Bennett, Documente on International Lffairs, p. 424 
to an end or were considerably moderated.

Without foar of attack, Poland could now oonsolidate its position in the former German provinces; momentarily Poland hed turnod Germen expansion in other directions and thereby gained time for rearmament. In viow of the unwillingness of Groat Britain and France to prevent treaty violation by Gormany, the Polleh-German agreement certainly serrod the immodiate interest of polend. Poland acquiescod in the Nazification of the Free City of Danzig, subject to the retention of oertain economio righta, and this contributed to the enormous strengthening of Germeny. ${ }^{1}$

Despite the 1934 understanding with Germany, Poland had no intention of breaking off from ita alliance with France. When Germeny reocoupiod the Rhinelend in Maroh 1936, Poland offered to mobilize if France did likewise, but Franoe doclinod, the confirming Poland's diagnosis of the Buropean situation.

When Germany annexed Austria in March 1938, Warsan did nothing. The official view was that Forelgn Policy Reports, June 1, 1936 
Danubian areas were of secondary importance and interest to Poland. In the midst of the subsequent Czochoslorak crials, Poland took what amounted to a pro-German attitudo.

For the moment, the Manich Conference and its aftermeth severely strained relations between Warsaw and Berlin. The two countries seomed to move together when theg made an agreoment on July 1, 1938, diverting German coal purahases from Crechoslovak1a to Poland, and the more important arrangement of October 17, 1938, by which Germany egreed to grant a $\$ 23,000,000$ credit to Poland. ${ }^{1}$ While Poland's independent forelgn policy, which reached its climax with the Teschen ultimetum, alieneted the west, warsaw believed more strongly than ever that if Czeohoslovakia could not depend on help from France, its own alliance with the French had become of little importance. France had acquiesoed in the Polish partitions at the end of the eighteenth century. Despite its alliance, France could do it again.

Notwithstanding the reduction of czechoslovakis

1. BüI1, Raymond Leslie, Op. C1t., p. 346 
as a result of the Hanich Conferenoe, wo Poles professed to believe that they could cont on the unileteral promise of Hitler not to menace their orn country, Others believed that German expansion would continue in the direction of the sontheast rather than turn toward the Baltic or the Ukraine. In his Sportspalast opeech of September 25, 1938 , H1tler declared he had informed chamberlain that Germany had no further territorial ambition in Burope. Ho also declared that the non-aggression pact with Poland of 1934 would "bring about lasting and continuous pacification", viow reiterated in his speech to the Reichstag of Jenuary 30, 1939. Por a people like the Poles, who pride themeelves on realism. Poland's independence must seem to rest on a very fragile basis if it depends merely on Hitler's self-restraint. The Third Relch has not postponed its efforts to realize its ambitions, and there are no indicatione that the Nazi regime has abandoned any of Germany's traditional designs, and these appirations conflict with the poles both in the Baltic and the Ukraine.

From the economic Viem, Poland's position with respect to Danzig is Lairly strong, should Germany 
annex the Free c1ty. Poland oould divert its trade to Gdynia, to the infury of Danzig. Should Hitler selze Danzig, it is problematical whether poland could hold the corridor on account of its short Fidh.

In an interviow of January 24, 1938, Foreign Minister Beok deolared thet, "the foremost prinolplo of polish policy is the maintaining of good relation with our neighbors, this is why the Polish Government attaches such great importance to its relations with Germany and soviet Ruseia.

"The second principle of our policy is loyal observance of the alliance of Polend to Prance and Roumania.

"The Third principle is to oppose any decision mede in matters concerning Poland without consulting ner.nl

Despite the efforts of both Germany and Italy to wean Poland away from France after Munich, Foreign Minister Beck declined to make any comments.

- Confronted by Hitler's destruction of Czechoslovakia in patent violation of the Munich agreement, Poland realized thet it would be the next object of German offensive, unless it showed determination to fight, 1. Iow York Timos, January 26, 1989 
could strengthen 1ts existing alliances, and find new sapport.

In the first week of March, Foreign Minister Safence of Rumanis visited Warsam and as a result the Pol1sh-Rumanian alliance was strengthened.

British public opinion was considerably aroused in the meantime, by Hitler's violation of the Manich agreement and the destruction of czechoslovakia. Realizing finally, that unless resietance was offered Nazi Germany would soon dominate Burope and a large part of the world, Prime Minister Chamberlain made a historic statement in the House of Commons, varch 31, 1939. At that timo he gave a temporary and unilateral assurance that "In the event of ang aotion which olearly threatened Pollah independence and which the Polieh government sccordingly considered it vital to resist with their national forces, Hia Majesty's Gorernmont would feel themselves bound at once to lend the polish Government all support in their porer. They have given the Polish Government an assurance to this effect. I may add that the French Government have authorized me to make it plain thet they stand in the seme position as do His Majesty!s Government, $n I$

1. Büll, Raymond Ie8110, Op. C1t., pp. 351-352 
When Iondon newepaper placed a rostriotive interpretation upon the Chamberlain otatement, a semi-official source declared that this pledge corered Danzig and the Corridor if Poland thought that 1ts independence was threatened there. By giving this pledge Groet Britain formally abandonned Its refusal to aocept obligations in Central Burope and in effect proclaimed its Irontier was not only on the Rhine but on the Vistula.

During the next weok Forelgn Minister Beok paid a visit to Iondon, and Britain and Poland agreod to enter into a permanent and reciprocel understanding to replace the assuranoe given by Chamberlain on Maroh 31, 1939.

Pending completion of the permanent agreement, Colonel Beck, Poland' Foreign Minister, deolared that Poland would consider itself under obligation to render assistance to Britain under the same conditions as Britain would be obligated to render assistance to Poland.

This mutual assistance pact applied to nany threat, direct or indirect, to the independenoe of either. $n^{2}$ Reports became numerous that Dansig would be

1. New York 11mes, Lpri1 25, 1939 
annexed by Germany on Hitler's birthday, April 20, before the Polish-British gueranteo had been finishod. A new factor disrupted these plans, if they existed, for on April 15, President Roosevelt addressed his dramatic appeal to Hitler and Musolini asking ten yoar plodge of non-aggression toward thirty atates, and proposing a peace conference.

Although the moserge did not specifically mention Danzig, Rooserelt probably saved the Free City from German occupation, and thereby averted momentarily at least, a great war. Hitler spent the next two weeks preparing a reply to the Rooserelt ploa. In an address to the Reichstag on April 28, the Funhrer not only rejected the president's offer for multilateral agreoment, but denounced the German-Polish non-aggression pect of January 1934.

He added, contrary to previons statements, that the treaty provisions giving Poland a corridor to the oen prevented for "all time the establishment of an anderstanding between Poland and Germany."

18 a result of abrogation of the 1934 pact, relations between Germeny and Poland became rery tense, and the Nazis reitersted that Danzig mast be returned to the Reioh. 
On Maroh 21, 1939, Hitler asked to bulld a highway -- reported to be fifteen miles in width -as well as railrosd across the so-called Corridor under Germen extraterritoriel jariodiotion. In return Hitler would recognize polish economio right in Dangig, inoluding the right to a freo harbor, acoept the present boundaries between the two countries, extend the non-aggression pact for twenty-five years.

Germany also demanded in the same note the return of Danzig as a "free city in the frame work of the German Reich. ${ }^{l}$

Polend could not possibly accept these terms, becanse the control of the Vistula River and Poland's outlet to the sea would have been placed at the complete mercy of Germany. Once Germany hed fortified Danzig, It could easily dominate Gdynis and the corridor. The position of Poland would be partioularly valnerable if Germeny hould build a fifteen milo wide road across Pomorze, policed by German soldiers. It would not be long before Germany entrenched at the mouth of the Vistula River would dominate poland proper and eventualig the whole of Eastern Europe extending to the Black Sea. As Frederiok II said in 1. Hitler, Adolph, Reiohstgg Speech of, Lpril 28, 1939 
1772. "Whoever possesses the mouth of the vistula and the eity of Danzig will be more the master than the king who rules there." ${ }^{I}$

on september first, nineteen handred and thirty-nine, Germany's army began an invasion of Poland and on September third, Britain and France declared war on Germany.

on September serenteonth, Russie invaded Poland.

On september twenty-ninth, Ruesia and Germany oignod an agreement to partition Poland. ${ }^{2}$ By thio agreement Germany acquired about three fifths of Poland and Russia took the remainder of the country. Germany's part was the western section of Poland, Ruesia's holdings lay to the east, bordering on Rnssia.

1. Wolfe, Henry C., "The Ghost of the Corridor," Iew Republ10, 98:240, 1937

2. The houlstilie Timos, September 29, 1939 
THE CONCLUSION 
THE COMCLUSION

Viewing the facts impartially, as the hiatorian does, we come to the conclusion that the land area of the Polish Corridor in the light of history belonged to Poland, though by no great margin. Rehearsing the facts of history. we find that there was a plece of land, smell in size and of irregalar shape, bordering on the Baltic sea, and of little intrinsic value, which was once nominally and actualdy Poliah. Then the Germans took it by force and hold it for a handred and fifty jears. The Peace Conference of paris returned it to Polend, with Germany protesting, and thereby separated East Prase1a from Germany proper. This was the "Corridor." The Corridor gare poland a sea coast and control of both sidea of the Vistula River to its mouth where the Free City of Danzig was situated.

We are forced to conclude then, thet in the light of history, the Corridor belonged to Poland. From the ethnio8l standpoint the population of the Corridor was Polish by a very small majority. The inhabitants of the Northern districts of 
Pomorse, who are known as Cashubes, are 2180 of Polish origin. They speak a Polish dialoct. In apite of policies of Germanization of this section by means of German colonists, the people have preserved their polish character intect. From 1871 to 1918 , that is, throughout the duration of the German Fmpire, the Pomeranian districto wero continuonely represented in the German parliament by polish deputies and on no occasion was a German elocted in elfteen electiona. Ethnioally, then, we mast conclude that the Corridor was Polish.

Finaliy, examination of the economic aspect of the problem convinces us that this territory is andoubtedly a part of the Polish economic anit rather than of the German; that it is needed as an outlet mach more by the poles than by the Germans; that much more inconrenience would be auffered by the poles than by the Germans living in East Prussia; that it would be a very groat economic injury not to permit the poles to have this outlet to the sea from their country under their own control.

1. Buell, Raymond Le8110, Op. CIt., p. 359 
All of these facts lead us to bat one conoluaion, and that is that Poland should have the "Corridor." For historical, ethnical and oconomic reasons, we believe that the paris Peace Conferenoe made proper diepostion of the land of the so-oalled "polish corridor." 


\section{BIBLIOGRAPHY}

Boors

Allison, W. H., Fay, S. B., Shearer, A. H. and Sh1pman, H. R., Guide to Historioel Ilterature, Men York. The vacmillan Co., I931.

Askenazy, szymon, Dantzig and Poland, Iondon, G. Llilon and UnTin, IgZI.

Asquith, H. H., The Genesis of the War, Ner York, Go0. H. Doran Co., 1923.

Baker, R. S., Foodron Wilson and the World Settlement, 3 vols., Nen York, Doubloday, Page and Co., 192E-1923.

Baker, R. S. and Dodd, W. E., Public papers of Woodrow Vilson, 6 rols., Now York, Harper and Bros., 1926-1927.

Bass, J. P., The Peace Tangle, Her York, The Macmillan Co., 1920.

Bowman, Isaiah, The New World, Yonkers-on-Hudson, The World Book Co., 1928.

Brackmann, Albert, Germany and Poland, 1934, pamphlet.

Buell, Raymond Leslie, Poland: Eer to Burope, Now York, Alfred A. Knopf, 1989.

Bulow, B. Von, Memolrs, 4 vols., Boston, Little Brown and Co., i931.

Clemencean, George, Grandeur and Migery of Vlotory, Paris, Plon, 1930.

Churchill, Winston, The World Crisis, Hew York, Charles Soribner's Sons, I92\%.

Crattwoll, C. R. M. F., $A$ History of the Great War, Oxford, The clarendon Press, 1934.

DewBon, William Harbutt, Germany Under the Treaty, New York, Iongmans, Green and Co., 1938. 
Dybosk1, Roman, Poland, How York, Charles soribner's Sons, 1933.

Fisher, Harold Henry, Amerioa and the Hew Poland, New York, The Nacmilian Co., 1928.

Fooh. Ferdinand, The Memoirs of Marghal Fooh, Ner York, Doubleday, Doran and Co.. 1931.

Grohem, K. W., HeT Governments of Eastern Earope. NeT York, H. Holt and Co., I92\%.

Grey, Edward, Trenty Fire Years, Hew York, Frederiok 4. stokes and Co., I925.

Haskins, C. H. and Lord R. H. Some Problems of the Perce Conference, Cambridge, Harvard University Tress, 1920.

Hazen, Charles Downes, Europe Since 1815, New York, H. HOIt and CO., 1923 .

Henderson, Brnest Flagg, A Short History of Germany, New York, The Macmilian Co., $1 \overline{9} \%$.

Hindenbarg, Paul, Von, Out of Wy Iffe, New York, Harper and Bros., I9zo.

Hitler, Adolph, Reichstag Speech, April 28, 1939, pamphlet.

House, Edward Mo, and Seymoux, C., that Really Happened at paris. New York, Charles seribñer B SOns, 1921.

Humphrey, Grace, Poland the Unexplored, Indianapel1s, The Bobbs-MerrIII Co., 1931.

Iansing, Robert, The Peace Negotiations, Personal Narrative, Boston, Houghton Mifilin änd Co., I921.

Iansing, R., The B1g Four and Others of the Peace Conference,

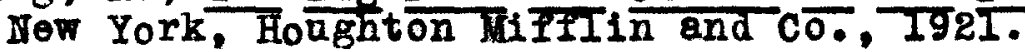

Larned History, The New, vol. VIII, Poland, C. N. Nichols, Springfieid, M88., pp. 6778-6824, 1923.

Iowinski-Carwin, Edward Henry, The political History of Poland, New York, The Polish Importing co., 1917. 
Lloyd George, David, Memoira of the Peace Conference, How Haren, Yale UnIVersity Prose, 1939.

Iudendorfe, Erich, Iudendorf's own Story, vol. I, How York, Harper and BroB., 1919.

Marriott, J. A. R., and Robertson, C. G., The Erolution of Pruss1a, Oxford, The clarendon Press, I915.

Hevin, Allan, Henry White, Thirty Years of Amerioan Diplomacy, Hew York, Herper and Bros., 1930.

Polmer, Froderick, Hewton D. Baker, Hew York, Dodd, Mead, and Co., 1931.

Pershing, J. J., Experiences in the World Wer, New York, Frederiek A. Stokes and Co. 198I.

Phillips, M. Alison, Poland, New York, H. Holt and Co., 1215.

Poincare, Raymond, The Kemoirs of Raymond Poincare, Iow York, Doubleday, Page and co., 1926-1930.

Pollsh Information Committeo, The, Poland's Case for Independence, New York, Dodd, Mead and Co.. 1918.

Segwour, C., The Intimate papers of Colonel House, Boston, Houghton IIfIIIn 00., 1926-1930.

Slawski, Dr. Stanislar, Poland's 10cess to the Sea, Iondon, Byre and Spottiemoode, 1926, pemphlet.

Smogorzewski, Casimir, Poland's lecess to the See, Iondon, Goorge Allen and Unîin, 1934.

Spender, Harold, The Prime Minister, New York, Geo, H. Doran and co., 1920 .

Stresemann, Gustav, H1s Diaries, Letters, and Papers, New York, The vacmilian co., I936-I937.

Temperley, H. W. V., A Hietory of the Poace Conference of paria, Iondon, H. Frowde, and Hodder and Stonghton, 1920-1924. 
Whooler-Bennett, J. W., Doonments on International Affairs, Iow York, Oxford UnIrereity Prese.

W11son, T., selected Iiterary and Politioal Papers and Addresses of Woodrow WIsOn, FeT Yor, Gros8et, 1926-1927.

Wolff, Theodor, The Eve of 1914, New York, Llfred 4. Hopf, 1936 .

\section{METSPAPRRS AID MAGAZINES}

Outloor, rol. 120, September-December, 1918.

The Contemporary Revier, March, 1920.

Atlantio Monthly, vol. 125, pp. 830-842, Jone, 1920.

Fore1gn Policy Reports. July, 1933.

Forelgn Affairs, July, 1935.

Fortnightly Revier, vol. 144, (II.S. 138), Jaly-December, 1985. Fore1gn Polloy Reports, June 1, 1936.

IeT Republie, vol. 92, October, 1937.

The Contemporary Reriow, January, 1939.

Ion York Times, January 25, 1939.

IOW York Times, April 25, 1939.

Forelgn Affaire, July, 1939.

The Loulsvillo Times, September 29, 1939. 